\title{
Differential Free Intracellular Calcium Release by Class II Antiarrhythmics in Cancer Cell Lines ${ }^{[\$}$
}

\author{
Marta Reyes-Corral, Naja M. Sørensen, Christopher Thrasivoulou, Prokar Dasgupta, \\ Jonathan F. Ashmore, and Aamir Ahmed \\ Centre for Stem Cells and Regenerative Medicine (M.R.-C., A.A.) and MRC Centre for Transplantation (P.D.), King's College \\ London, London, United Kingdom; Sophion Bioscience A/S, Ballerup, Denmark (N.M.S.); and Departments of Cell and \\ Developmental Biology (C.T.) and Neuroscience, Physiology and Pharmacology, and The Ear Institute (J.F.A.), University College \\ London, London, United Kingdom
}

Received October 12, 2018; accepted January 2, 2019

\section{ABSTRACT}

Class II antiarrhythmics or $\beta$-blockers are antisympathetic nervous system agents that act by blocking $\beta$-adrenoceptors. Despite their common clinical use, little is known about the effects of $\beta$-blockers on free intracellular calcium $\left(\mathrm{Ca}_{\mathrm{i}}^{2+}\right)$, an important cytosolic second messenger and a key regulator of cell function. We investigated the role of four chemical analogs, commonly prescribed $\beta$-blockers (atenolol, metoprolol, propranolol, and sotalol), on $\mathrm{Ca}_{\mathrm{i}}^{2+}$ release and whole-cell currents in mammalian cancer cells (PC3 prostate cancer and MCF7 breast cancer cell lines). We discovered that only propranolol activated free $\mathrm{Ca}_{\mathrm{i}}^{2+}$ release with distinct kinetics, whereas atenolol, metoprolol, and sotalol did not. The propranololinduced $\mathrm{Ca}_{i}^{2+}$ release was significantly inhibited by the chelation of extracellular calcium with ethylene glycol tetraacetic acid (EGTA) and by dantrolene, an inhibitor of the endoplasmic reticulum (ER) ryanodine receptor channels, and it was completely abolished by 2-aminoethoxydiphenyl borate, an inhibitor of the ER inositol-1,4,5-trisphosphate $\left(\mathrm{IP}_{3}\right)$ receptor channels. Exhaustion of ER stores with 4-chloro- $m$-cresol, a ryanodine receptor activator, or thapsigargin, a sarco/ER $\mathrm{Ca}^{2+}$ ATPase inhibitor, precluded the propranolol-induced $\mathrm{Ca}_{\mathrm{i}}^{2+}$ release. Finally, preincubation of cells with sotalol or timolol, nonselective blockers of $\beta$-adrenoceptors, also reduced the $\mathrm{Ca}_{\mathrm{i}}^{2+}$ release activated by propranolol. Our results show that different $\beta$-blockers have differential effects on whole-cell currents and free $\mathrm{Ca}_{\mathrm{i}}^{2+}$ release and that propranolol activates store-operated $\mathrm{Ca}_{\mathrm{i}}^{2+}$ release via a mechanism that involves calcium-induced calcium release and putative downstream transducers such as $\mathrm{IP}_{3}$. The differential action of class II antiarrhythmics on $\mathrm{Ca}_{i}^{2+}$ release may have implications on the pharmacology of these drugs.

\section{Introduction}

Class II antiarrhythmics or $\beta$-blockers have been in clinical use for the treatment of cardiovascular conditions such as angina and hypertension for more than five decades (Black et al., 1964; Chobanian et al., 2003). The cardioprotective effects of class II antiarrhythmics are linked to the inhibition of $\beta$-adrenoceptor $\left(\beta\right.$-AR) signaling. There are three types of $\beta$-ARs: $\beta_{1}$-AR, found mainly in cardiac cells; $\beta_{2}$-AR, present in bronchial and vascular tissue; and $\beta_{3}$-AR, largely expressed in adipose tissue. $\beta$-ARs are also expressed in many primary and metastasized tumors (Daly and McGrath, 2011; Cole and Sood, 2012).

Upon stimulation by catecholamines, $\beta$-AR signaling results in elevated cAMP levels and activation of the cAMP-dependent protein kinase A (Naga Prasad et al., 2001; Cole and Sood,

This work was supported by the Prostate Cancer Research Centre [UK Charity no. 1156027] (A.A.) and a Ph.D. studentship sponsored by the National Institute for Health Research Biomedical Research Centre at Guy's and St. Thomas' National Health Service Foundation Trust and King's College London (M.R.-C.).

https://doi.org/10.1124/jpet.118.254375.

S This article has supplemental material available at jpet.aspetjournals.org.
2012), which targets L-type $\mathrm{Ca}^{2+}$ channels ( $\left.\mathrm{Ca}_{\mathrm{V}} 1.2\right)$, activating a calcium influx (Weiss et al., 2013). Few reports have analyzed the direct effects of $\beta$-blockers on free intracellular calcium $\left(\mathrm{Ca}_{\mathrm{i}}^{2+}\right)$ although previous studies have suggested that there is a reduction in the levels of free $\mathrm{Ca}_{\mathrm{i}}^{2+}$ in platelets and erythrocytes of hypertensive patients treated with $\beta$-blockers (Erne et al., 1984; Baumgart et al., 1986).

Free $\mathrm{Ca}_{\mathrm{i}}^{2+}$ is a potent second messenger that regulates many different cellular processes, including cell proliferation, cell differentiation, gene transcription, and apoptosis (Berridge et al., 2000; Carafoli et al., 2001). The level of cytosolic-free calcium $(\sim 100 \mathrm{nM})$ is tightly regulated, and most $\mathrm{Ca}_{\mathrm{i}}^{2+}$ resides in intracellular stores, which in nonmuscle cells are principally located in the endoplasmic reticulum (ER) (Berridge et al., 2003). $\mathrm{Ca}_{\mathrm{i}}^{2+}$ can be released from the ER through ryanodine receptor (RyR) (Zorzato et al., 1990) and inositol1,4,5-trisphosphate $\left(\mathrm{IP}_{3}\right)$ receptor channels (Nixon et al., 1994). Calcium transients resulting from $\mathrm{Ca}^{2+}$ influx or $\mathrm{Ca}_{\mathrm{i}}^{2+}$ release give rise to fast $\mathrm{Ca}^{2+}$ spikes or slower oscillatory waves that, depending on their kinetics and amplitude, translate to different cellular funtions (Berridge et al., 2003).

ABBREVIATIONS: 2-APB, 2-aminoethoxydiphenyl borate; $\beta$-AR, $\beta$-adrenoceptor; $\mathrm{Ca}_{\mathrm{i}}^{2+}$, free intracellular calcium; CICR, calcium-induced calcium release; 4-CmC, 4-chloro-m-cresol; DMSO, dimethyl sulfoxide; $\mathrm{ER}$, endoplasmic reticulum; IP 3 , inositol-1,4,5-trisphosphate; MPRC, membrane potential regulating compound; PBS, phosphate-buffered saline; RyR, ryanodine receptor; SERCA, sarco/endoplasmic reticulum $\mathrm{Ca}^{2+} \mathrm{ATPase}$ TRP, transient receptor potential channels. 
Despite the critical role of free $\mathrm{Ca}_{\mathrm{i}}^{2+}$ as a regulator of cell function, the effects of $\beta$-blockers on the mobilization and kinetics of $\mathrm{Ca}_{\mathrm{i}}^{2+}$ have received limited attention. Some reports regarding the regulation of calcium by $\beta$-blockers exist and include the investigations of $\mathrm{Ca}_{\mathrm{i}}^{2+}$ levels in different disease models of heart failure or hypertension (Doi et al., 2002; Reiken et al., 2003; Tuncay et al., 2013; Cseplo et al., 2016). Other studies have examined the effects of $\beta$-blockers on $\beta$-adrenergic mediated calcium entry (e.g., after activation with $\beta$-AR agonists, such as isoproterenol or albuterol) and their role on cell contraction and vasorelaxation in different tissues and cell types (Sakanashi and Takeo, 1983; Yao et al., 2003; Priviero et al., 2006; Shahbaz et al., 2011; Cekic et al., 2013; Keller et al., 2014) (see Supplemental Table 1 for details). Surprisingly, the direct activation of free $\mathrm{Ca}_{\mathrm{i}}^{2+}$ release by $\beta$-blockers has not been examined before in excitable or nonexcitable cells.

We have previously shown that several membrane potential regulating compounds (MPRCs), including the antiarrhythmics amiodarone and dofetilide, activate store-operated $\mathrm{Ca}^{2+}{ }_{\mathrm{i}}$ release in mammalian cancer cells (Petrou et al., 2017). Several epidemiologic studies have reported that the use of $\beta$-blockers correlates with a lower incidence of cancer progression and mortality for prostate (Perron et al., 2004; Grytli et al., 2013), breast (Powe et al., 2010; Barron et al., 2011; Melhem-Bertrandt et al., 2011), and skin cancers (De Giorgi et al., 2011; Lemeshow et al., 2011; De Giorgi et al., 2017).

We asked whether $\beta$-blockers could activate $\mathrm{Ca}_{\mathrm{i}}^{2+}$ release in cancer cells. We concentrated on four commonly used $\beta$-blockers, including two $\beta_{1}$-selective $\beta$-blockers-atenolol and metoprolol -and two nonselective $\beta$-blockers-propranolol and sotalol. We used PC3 and MCF7, prostate and breast cancer cell lines, respectively, to measure $\mathrm{Ca}_{\mathrm{i}}^{2+}$ release by ratiometric live calcium imaging. In addition, we used a medium throughput patch-clamp system to measure ionic currents in the cells. The results show that 1) only propranolol activated a $\mathrm{Ca}_{\mathrm{i}}^{2+}$ release, with distinct kinetics and amplitude; 2) the propranolol activation of $\mathrm{Ca}_{\mathrm{i}}^{2+}$ stores was mediated by calcium-induced calcium release (CICR); and 3 ) the four $\beta$-blockers regulate endogenous whole-cell currents in cancer cell lines. Our results show differential activation of calcium stores and free $\mathrm{Ca}_{\mathrm{i}}^{2+}$ release by several class II antiarrhythmics in nonexcitable, cancer cells and may have important implications for the mechanism of action and pharmacology of these $\beta$-blockers.

\section{Materials and Methods}

Compounds. All $\beta$-blockers were purchased from Sigma-Aldrich (Gillingham, UK). Stock solutions were prepared in dimethyl sulfoxide (DMSO; Sigma-Aldrich) for atenolol and propranolol or in phosphate buffer saline (PBS), pH 7.4, without $\mathrm{Ca}^{2+}$ or $\mathrm{Mg}^{2+}$ (cat. no. 10010; Gibco ThermoFisher, Loughborough, UK) for metoprolol and sotalol according to the manufacturer's instructions. The following are the systematic names for the $\beta$-blockers: atenolol (cat. no. A7655), ( \pm )-4-[2hydroxy-3-[(1-methylethyl)amino]propoxy]benzeneacetamide; metoprolol tartrate (cat. no. M5391), ( \pm )1-(isopropylamino)-3-[p-( $\beta$-methoxyethyl)phenoxy]-2-propanol (+)-tartrate salt; propranolol hydrochloride (cat. no. P8688): (S)-1-isopropylamino-3-(1-naphthyloxy)-2-propanol hydrochloride; and sotalol hydrochloride (cat. no. S0278), N-[4-[1-hydroxy-2(isopropylamino)ethyl]phenyl]methanesulfonamide hydrochloride (see Supplemental Fig. 1 for chemical structures). For all $\beta$-blockers, two different lots were purchased and tested in our experiments. Loxapine (cat. no. L106; Sigma-Aldrich), previously shown to activate store-operated free $\mathrm{Ca}_{\mathrm{i}}^{2+}$ release via CICR in cancer cells (Petrou et al., 2017), was used as a positive control for some live $\mathrm{Ca}_{\mathrm{i}}^{2+}$ imaging experiments. Timolol (cat. no. T6394; Sigma-Aldrich) was used as an additional nonselective $\beta$-blocker to investigate the contribution of $\beta$-ARs to $\mathrm{Ca}_{\mathrm{i}}^{2+}$ release. Ethylene glycol tetraacetic acid (EGTA), dantrolene, 4-chloro- $m$-cresol (4-CmC), thapsigargin (Sigma-Aldrich), and 2-aminoethoxydiphenyl borate (2-APB; Tocris Bioscience, Abingdon, UK) were also used in some experiments (see later). Stock solutions were prepared in DMSO (dantrolene, 2-APB, and thapsigargin), ethanol (4-CmC), or PBS (EGTA).

Cell Culturing. PC3 prostate cancer and MCF7 breast cancer cell lines were obtained from the American Type Culture Collection (Teddington, UK). Details of cell culture procedures have been described elsewhere (Thrasivoulou et al., 2013; Petrou et al., 2017). Briefly, cells were maintained in RPMI 1640 medium (Gibco ThermoFisher) supplemented with $10 \%$ fetal bovine serum and $5 \mathrm{mM}$ L-glutamine and cultured at $37^{\circ} \mathrm{C}$ in a humidified incubator with $5 \%$ $\mathrm{CO}_{2}$ and $21 \% \mathrm{O}_{2}$ atmosphere. For live calcium imaging experiments, $10^{5}$ cells were seeded in 35-mm FluoroDishes (World Precision Instruments, Hitchin, UK), and experiments were performed in at least four to eight different passages (passage numbers 23-38 for PC3 cells and 35-44 for MCF7 cells).

Intracellular Live Calcium Imaging. Free $\mathrm{Ca}_{i}^{2+}$ release was measured as a change in the ratio of Fluo-4/FuraRed (free calcium/ bound calcium) over time. The two indicators have reciprocal shifts in intensity owing to calcium binding and are used together in a ratiometric probe strategy described previously (Wang et al., 2010b; Thrasivoulou et al., 2013; Petrou et al., 2017). Briefly, cells were grown as a monolayer in $35 \mathrm{~mm}$ FluoroDishes for 3 to 4 days. Before imaging, the cells were incubated for $30-40$ minutes at $37^{\circ} \mathrm{C}$ with the acetoxymethyl ester derivatives of the calcium indicators Fluo-4 and FuraRed (ThermoFisher Scientific) at 1.1 and $1.4 \mu \mathrm{g} / \mathrm{ml}$, respectively. Cells were washed $(3 \times)$ with and replaced in $1 \mathrm{ml}$ PBS without $\mathrm{Ca}^{2+}$ or $\mathrm{Mg}^{2+}$ (Gibco ThermoFisher, as described) for live calcium imaging, performed using an Olympus FluoView FV100 confocal microscope (Olympus, UK) equipped with a $20 \times / 0.75$ NA objective and a temperature-controlled chamber at $37^{\circ} \mathrm{C}$. Calcium indicators were excited with an argon laser at $488 \mathrm{~nm}$, and fluorescence was recorded every 2.2 seconds in the green channel for Fluo-4 (500-580 nm) and in the red channel for FuraRed $(630-730 \mathrm{~nm})$. Confocal imaging was started and, after a baseline was achieved, $\mathrm{Ca}_{\mathrm{i}}^{2+}$ release was measured by applying $\beta$-blockers to the FluoroDish as a bolus, at a volume of $0.5-5 \mu \mathrm{l}$, to achieve a final $\beta$-blocker concentration of $25,50,100,150$, or $250 \mu \mathrm{M}$; vehicle controls were performed using a similar protocol. Data acquisition was performed using Olympus FV10-ASW 4.2 software.

Although the PBS used here is nominally $\mathrm{Ca}^{2+}$ free, the residual $\mathrm{Ca}^{2+}$ concentration in PBS was measured to be $>60 \mu \mathrm{M}$ in this solution (Petrou et al., 2017). In some experiments, 5 mM EGTA was added to the PBS used as imaging media to chelate free residual $\mathrm{Ca}^{2+}$; cells were preincubated for 5 minutes before imaging was started. We have previously shown that using 5 mM EGTA in PBS reduces the residual free $\mathrm{Ca}^{2+}$ to $<10 \mathrm{nM}$ (Petrou et al., 2017). In other experiments, for the pharmacologic characterization of the mechanisms of $\mathrm{Ca}_{i}^{2+}$ store activation, cells were preincubated with the following: 1) $10 \mu \mathrm{M}$ dantrolene for 5 minutes at $37^{\circ} \mathrm{C}$ to inhibit the ER RyR channels (Zhao et al., 2001); 2) $1 \mathrm{mM} 4$-CmC for 12 minutes at $37^{\circ} \mathrm{C}$ to activate RyR channels and exhaust the $\mathrm{Ca}_{\mathrm{i}}^{2+} \mathrm{ER}$ stores (Zorzato et al., 1993); 3) varying concentrations (1, 25, 50, or $100 \mu \mathrm{M})$ of 2 -APB for 10 minutes at $37^{\circ} \mathrm{C}$ to inhibit the $\mathrm{ER} \mathrm{IP}_{3}$ receptor channels (Maruyama et al., 1997); 4) $5 \mu \mathrm{M}$ thapsigargin for 15-20 minutes at $37^{\circ} \mathrm{C}$ to discharge $\mathrm{Ca}_{\mathrm{i}}^{2+}$ from the ER (Thastrup et al., 1990); or 5) $250 \mu \mathrm{M}$ sotalol or timolol (nonselective $\beta$-blockers) for 2 minutes at $37^{\circ} \mathrm{C}$ for blockade of $\beta$-ARs (Baker, 2005).

Data Analysis and Statistics. Data from live calcium imaging experiments were analyzed for time kinetics and amplitude as described previously (Thrasivoulou et al., 2013) using a Mathematica script (Wolfram, Hanborough, UK) (Petrou et al., 2017). The kinetics of the calcium waveform were characterized by different time constants: rise time (time from baseline to peak), dwell time (duration of the plateau 
phase), and fall time (time to return to baseline). The amplitude of the response was calculated as a fold increase in fluorescence intensity from baseline to peak $\left(\Delta F / F_{0}\right.$, where $\Delta F=F-F_{0}$ and $F$ is the maximum fluorescence intensity over basal level, $F_{0}$ ). Data were analyzed using the D'Agostino-Pearson test for normal distribution and the Mann-Whitney $U$ test for statistical significance using MedCalc (Ostend, Belgium), and plotted using OriginPro 2016 (OriginLab, Northampton, MA).

Automated Medium-Throughput Electrophysiology. Endogenous whole-cell currents of PC3 cells in response to the application of $\beta$-blockers were measured using the QPatch automated cell patchclamp system (Sophion Bioscience, Ballerup, Denmark), as described previously (Petrou et al., 2017). PC3 cells were cultured and harvested using Detachin (Genlantis, San Diego, CA) and kept in the QStirrer of the QPatch for up to 4 hours before the automatic preparation. The cells were transferred to the QFuge, centrifuged, and washed $2 \times$ in extracellular solution (see following) before being applied to the measuring site in the QPlate of the QPatch. A pressure of $-70 \mathrm{mBar}$ was applied to obtain positioning and sealing of the cells, and a wholecell protocol with pressure pulses at $-150 \mathrm{mBar}$ was used to obtain whole-cell formation. Gigaseals were formed upon execution of a combined suction/voltage protocol. The intracellular solutions and compounds were applied by eight pipettes. The intracellular solution contained (in millimolar concentrations): $5.3 \mathrm{CaCl}_{2}, 1.7 \mathrm{MgCl}_{2}$, 10 EGTA, $10 \mathrm{HEPES}, 120 \mathrm{KCl}$, and $4 \mathrm{Na}_{2}$-ATP; with pH 7.2, osmolarity of $295 \mathrm{mOsm}$, and a calculated free calcium concentration of $680 \mathrm{nM}$. The extracellular solution contained (in millimolars): $2 \mathrm{CaCl}_{2}, 1 \mathrm{MgCl}_{2}$, $10 \mathrm{HEPES}, 4 \mathrm{KCl}$, and $145 \mathrm{NaCl}$, with $\mathrm{pH}$ 7.4, and osmolarity adjusted to 285-295 mOsm. Currents were recorded using a command ramp from -120 to $+120 \mathrm{mV}$ at $0.5 \mathrm{mV} / \mathrm{ms}$ every 3 seconds, with a holding voltage of $-10 \mathrm{mV}$ between executions of the ramps. Data were sampled at $5 \mathrm{kHz}$ and filtered using a fourth-order Bessel filter.

Six different concentrations of individual drugs were used: increasing concentrations of the $\beta$-blocker from 0 to $500 \mu \mathrm{M}$ were applied sequentially on the same cell. The QPatch system implements fine microfluidic control of the drug delivery time, and complete solution changes were made within 500 milliseconds. Average currents at +100 and $-100 \mathrm{mV}$ were analyzed to explore the concentration dependence of the modulation of endogenous whole-cell currents by $\beta$-blockers; statistical significance was calculated with the Wilcoxon test (MedCalc). Current-voltage (I-V) curves of control versus $\beta$-blocker were also constructed. Additional analysis of medium-throughput data from QPatch was carried out using Matlab (Mathworks, Natick, MA).

Real-Time Polymerase Chain Reaction . Total RNA was purified from PC3 cells by using the RNeasy Plus kit (Qiagen, Manchester, UK) and reverse-transcribed with the Omniscript RT kit (Qiagen), according to the manufacturer's instructions. Polymerase chain reaction was performed with the SYBR-Green PCR master mix (Applied Biosystems, Foster City, CA) using a Bio-Rad (Watford, UK) CFX384 thermocycler. Expression levels of the genes of interest were normalized to GAPDH or $\beta$-actin, and melting curves were analyzed using Bio-Rad CFX Manager to verify the products. The following primers were purchased from Sigma-Aldrich: $\beta_{1}$-AR (ADRB1) sense 5'-TACGGCTCCTTCTTCTGCGA-3' and antisense $5^{\prime}$-CAGGTACACGAAGGCCATGAT-3'; $\beta_{2}$-AR (ADRB2) sense $5^{\prime}$-CATTGAGACCCTGTGCGTGA-3' and antisense 5'-AGGGCTTTGTGCTCCTTCAA-3'; $\beta_{3}$-AR (ADRB3) sense $5^{\prime}$-GTTTTCGTGGTGGCTACGC$3^{\prime}$ and antisense 5'-CCTAGCCAGTTCAGGGCAAG-3'; glyceraldehyde 3-phosphate dehydrogenase (GAPDH) sense 5'-CGGATTTGGTCGTATTGGGC-3' and antisense 5'-TGGTCATGAGTCCTTCCACG-3'; $\beta$-actin (ACTB) sense 5'-CTGTGCTATCCCTGTACGCC-3' and antisense 5'-ATCTTCATTGTGCTGGGTGCC-3' (annealing at $60^{\circ} \mathrm{C}$ for 40 cycles; 70 melting curve reads off, from 60 to $95^{\circ} \mathrm{C}$ ).

\section{Results}

Propranolol Activates $\mathrm{Ca}_{\mathrm{i}}^{2+}$ Release in Cancer Cells with Distinct Kinetics but Other $\beta$-Blockers Do Not. The addition of $50 \mu \mathrm{M}$ propranolol to the extracellular solution caused a change in the ratio of Fluo-4/FuraRed in PC3 cells (Fig. 1), indicating release of free $\mathrm{Ca}_{\mathrm{i}}^{2+}$; there was no observable $\mathrm{Ca}_{i}^{2+}$ release in response to atenolol, metoprolol, and sotalol (Fig. 2A). Similar results were observed in MCF7 breast cancer cells, indicating that this phenomenon is not cell line specific (Fig. 2B). We also tested various concentrations of $\beta$-blockers (Fig. 3) within the pharmacologic range (Joint Formulary Committee, 2017).

Three of the $\beta$-blockers used did not induce free $\mathrm{Ca}_{\mathrm{i}}^{2+}$ release in either PC3 or MCF7 cancer cell lines (Fig. 2). We performed additional validation experiments to exclude the possibility that the lack of $\mathrm{Ca}_{i}^{2+}$ release by atenolol, metoprolol, and sotalol may have been due to cellular or technical factors. First, to confirm that the cells remained responsive to free $\mathrm{Ca}_{\mathrm{i}}^{2+}$ release, loxapine, a compound previously shown to induce $\mathrm{Ca}_{\mathrm{i}}^{2+}$ release in cancer cells (Petrou et al., 2017), was used as a positive control. In these experiments, atenolol, metoprolol, or sotalol were first added to the cells for 10 minutes, followed by loxapine in live calcium imaging experiments. There was no $\mathrm{Ca}_{\mathrm{i}}^{2+}$ release in response to the three $\beta$-blockers $(n=3)$; however, the addition of loxapine to the same cells activated $\mathrm{Ca}_{\mathrm{i}}^{2+}$ release (Fig. 4). Second, we procured different lots for the three drugs from the vendor (Sigma-Aldrich) and tested these in live $\mathrm{Ca}_{\mathrm{i}}^{2+}$ imaging experiments. $\mathrm{No}_{\mathrm{i}}^{2+}$ release occurred in response to addition of any of the different lots of atenolol, metoprolol, or sotalol. The effect of the solvent vehicle used for drug suspension (either DMSO or ethanol) was tested and was found to have no effect on any of the responses (i.e., only propranolol, but not atenolol, metoprolol, or sotalol, induced $\mathrm{Ca}_{\mathrm{i}}^{2+}$ release) (Supplemental Fig. 2).

The waveform of $\mathrm{Ca}_{i}^{2+}$ release was used to measure the amplitude and the time kinetics (rise, dwell, and fall times) as described elsewhere (Thrasivoulou et al., 2013). Figure 5 shows the distinct time constants of the $\mathrm{Ca}_{\mathrm{i}}^{2+}$ release in response to $50 \mu \mathrm{M}$ propranolol in PC3 and MCF7 cells; similar kinetics were observed in both cell lines.

Role of Calcium-Induced Calcium Release Mechanism in the Propranolol-Induced $\mathrm{Ca}_{\mathbf{i}}^{2+}$ Release. We tested the hypothesis that CICR is the mechanism by which propranolol-induced $\mathrm{Ca}_{\mathrm{i}}^{2+}$ release occurs in cancer cells. Four sets of experiments were performed. First, we added $5 \mathrm{mM}$ EGTA to chelate the residual $\mathrm{Ca}^{2+}(>60 \mu \mathrm{M}$ in the PBS used for calcium imaging experiments), as it is known that even micromolar levels of extracellular $\mathrm{Ca}^{2+}$ can activate CICR pathways (Berridge et al., 2003; Endo, 2009). The addition of 5 mM EGTA, which chelates extracellular $\mathrm{Ca}^{2+}$ concentration to $<10 \mathrm{nM}$ (Petrou et al., 2017), significantly inhibited the propranolol-induced $\mathrm{Ca}_{\mathrm{i}}^{2+}$ release (Fig. 6).

Second, we used dantrolene and 4-CmC, modulators of RyR channels found in the ER (Zorzato et al., 1993; Zhao et al., 2001), to determine whether the ER calcium stores were activated in response to extracellular addition of propranolol. Incubation with $10 \mu \mathrm{M}$ dantrolene, an inhibitor of RyRs, significantly inhibited the $\mathrm{Ca}_{\mathrm{i}}^{2+}$ release induced by propranolol (Fig. 6). Incubation of cells with $1 \mathrm{mM} 4-\mathrm{CmC}$, an activator of RyRs that is known to induce $\mathrm{Ca}_{\mathrm{i}}^{2+}$ stores (Supplemental Fig. 3A), also inhibited the propranolol-induced $\mathrm{Ca}_{\mathrm{i}}^{2+}$ release (Fig. 6).

Third, we used 2-APB, an inhibitor of $\mathrm{IP}_{3}$-induced $\mathrm{Ca}_{\mathrm{i}}^{2+}$ release from the $\mathrm{IP}_{3}$ receptor channels located in the ER (Maruyama et al., 1997) and also known to inhibit various 

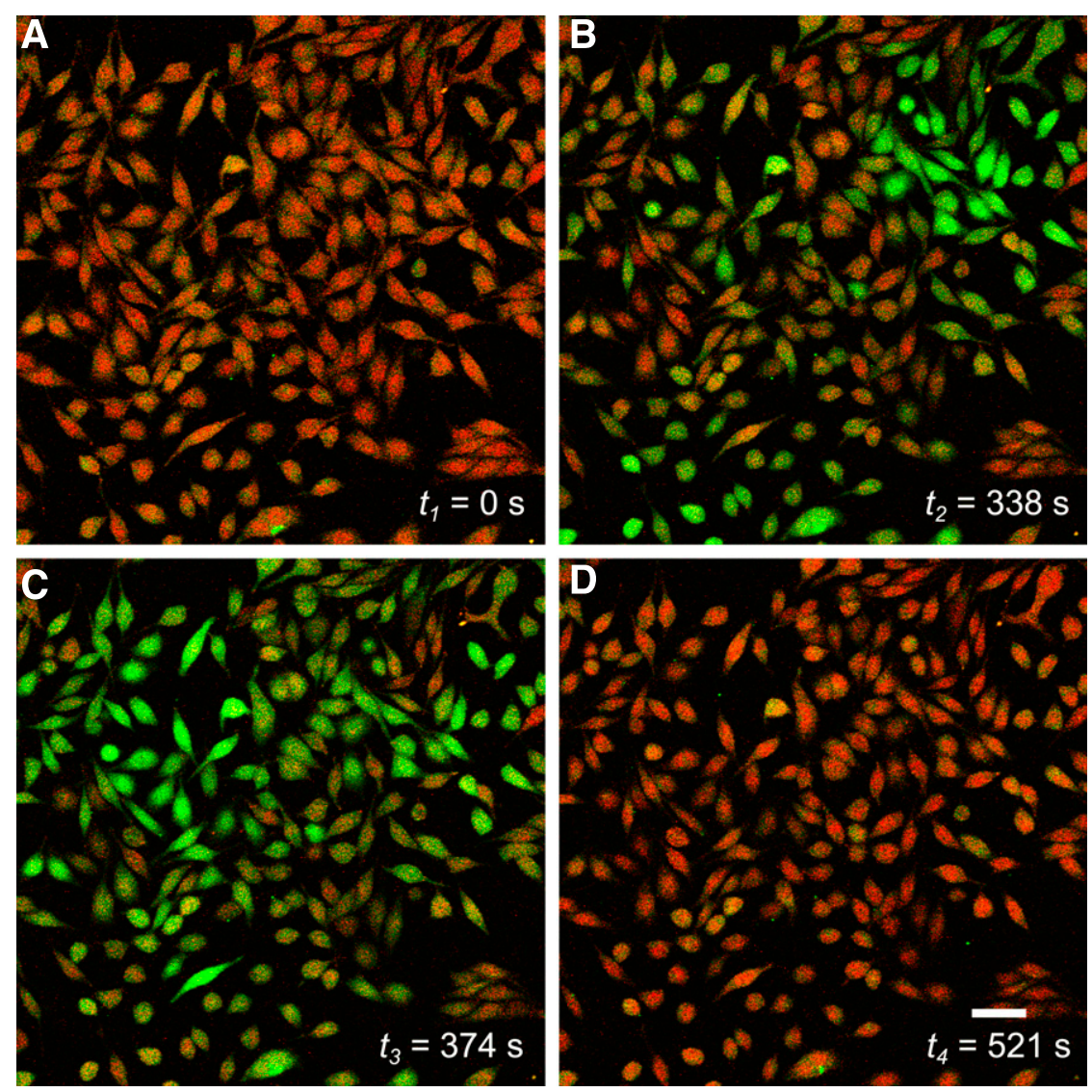

Fig. 1. Intracellular calcium $\left(\mathrm{Ca}_{\mathrm{i}}^{2+}\right)$ release in PC3 cells in response to $50 \mu \mathrm{M}$ propranolol. PC3 cells were loaded with the calcium indicators Fluo-4 (green fluorescence, an indicator of free calcium) and FuraRed (red fluorescence, an indicator of bound calcium) and monitored by time-lapse video microscopy every 2.2 seconds using an Olympus FluoView FV100 confocal microscope. Representative snapshots of free $\mathrm{Ca}_{\mathrm{i}}^{2+}$ release at four time points (A-D) are shown: (A) Baseline before the addition of propranolol; (B) approximately $30 \%$ of cells in the observable frame undergoing $\mathrm{Ca}_{\mathrm{i}}^{2+}$ release at $t=$ 338 seconds, as observed by the simultaneous increase in Fluo-4 fluorescence and decrease in FuraRed signal; (C) peak of the $\mathrm{Ca}_{\mathrm{i}}^{2+}$ release response $(t=$ 374 seconds) with almost all cells showing a response (green); and (D) cells returning to baseline after the propranolol-induced $\mathrm{Ca}_{\mathrm{i}}^{2+}$ release. Scale bar, $50 \mu \mathrm{m}$, original magnification, $20 \times$.
TRP ion channels (Xu et al., 2005; Togashi et al., 2008). Incubation with $50 \mu \mathrm{M}$ 2-APB, a concentration within the range of $\mathrm{IC}_{50}$ values for the inhibition of $\mathrm{IP}_{3}$-induced $\mathrm{Ca}_{\mathrm{i}}^{2+}$ release (Maruyama et al., 1997; Bootman et al., 2002; Saleem et al., 2014), also abolished the propranolol-induced $\mathrm{Ca}_{\mathrm{i}}^{2+}$ release (Fig. 6). Similar results were observed when cells were incubated with 25 and $100 \mu \mathrm{M}$ 2-APB (Supplemental Fig. 4).

Fourth, incubation with $5 \mu \mathrm{M}$ thapsigargin, an inhibitor of the sarco/endoplasmic reticulum $\mathrm{Ca}^{2+}$ ATPase or SERCA (Thastrup et al., 1990), completely abolished the propranololinduced $\mathrm{Ca}_{\mathrm{i}}^{2+}$ release (Fig. 6). Thapsigargin, like 4-CmC, discharges the $\mathrm{Ca}_{\mathrm{i}}^{2+}$ from thapsigargin-sensitive stores (e.g., the ER; Supplemental Fig. 3B) and has been previously used to investigate ligand-induced $\mathrm{Ca}_{\mathrm{i}}^{2+}$ release (Thrasivoulou et al., 2013). In summary, these results indicate that the propranolol-induced $\mathrm{Ca}_{\mathrm{i}}^{2+}$ release is likely to be a CICRfacilitated mechanism in which extracellular calcium contributes to the activation of $\mathrm{Ca}_{\mathrm{i}}^{2+}$ release from the ER through RyR channels and $\mathrm{IP}_{3}$ receptor channels.

$\boldsymbol{\beta}$-ARs and Propranolol-Induced $\mathrm{Ca}_{\mathbf{i}}^{2+}$ Release. The involvement of $\beta$-ARs in general for the activation of $\mathrm{Ca}_{\mathrm{i}}^{2+}$ release by propranolol was investigated by using two different nonselective $\beta$-blockers: sotalol and timolol. We tested the hypothesis that blocking $\beta$-ARs using the known nonselective $\beta$-blockers would interfere with the propranolol-induced $\mathrm{Ca}^{2+}$ release. Neither sotalol nor timolol activated $\mathrm{Ca}_{\mathrm{i}}^{2+}$ release in PC3 cells, and this was further confirmed by treating the same cells with loxapine (Fig. 4C; Supplemental Fig. 5); however, incubating the cells with either sotalol or timolol significantly inhibited the propranolol-induced $\mathrm{Ca}^{{ }^{2+}}$ release
(Fig. 7A), suggesting that propranolol exerts its function via the $\beta$-ARs. The $\mathrm{Ca}_{\mathrm{i}}^{2+}$ release induced by loxapine (a dibenzoxazepine) remained unaffected by preincubation with sotalol or timolol (Fig. 7B).

Electrophysiological Characteristics of $\beta$-Blockers on Medium-Throughput Whole-Cell Currents in PC3 Cells. The electrophysiological characteristics of the four $\beta$-blockers on the endogenous currents in nonexcitable cancer cells, are not known (see Supplemental Table 2 for details on the electropharmacology of $\beta$-blockers in other cell types). We sought to establish a basic characterization of the effects of $\beta$-blockers on the endogenous whole-cell currents in PC3 cells using medium-throughput recording. Six concentrations of each $\beta$-blocker were tested in the cells, based on the pharmacologic doses (Supplemental Fig. 1; Joint Formulary Committee, 2017) and the $\mathrm{IC}_{50}$ values described previously (Supplemental Table 2), following a voltage-clamp protocol with a command ramp from -120 to $+120 \mathrm{mV}$. Figure 8 shows the concentration dependence of whole-cell current regulation by $\beta$-blockers in PC3 cells at positive $(+100 \mathrm{mV})$ and a negative $(-100 \mathrm{mV})$ potential. $\beta$-Blockers regulate whole-cell currents with distinct features (Fig. 8, A-D); atenolol inhibited whole-cell currents at positive, but not at negative potentials, and metoprolol activated currents at negative and positive potentials. Both these effects were concentration-dependent.

In contrast, propranolol enhanced whole-cell currents at both positive and negative potentials at concentrations $<8.4 \mu \mathrm{M}$. At higher concentrations (i.e., $56-500 \mu \mathrm{M}$ ), currents were inhibited, which we ascribe to nonspecific effects at these very high $(>56 \mu \mathrm{M})$ levels of the drug. Sotalol did not cause significant alterations to endogenous currents at any of the 
A PC3 cells

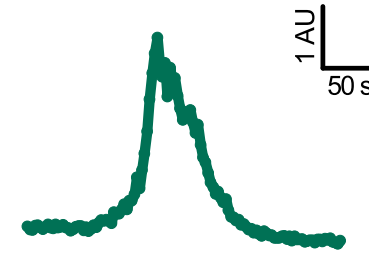

Propranolol

B MCF7 cells

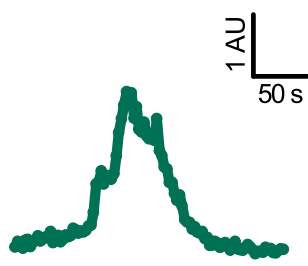

Propranolol
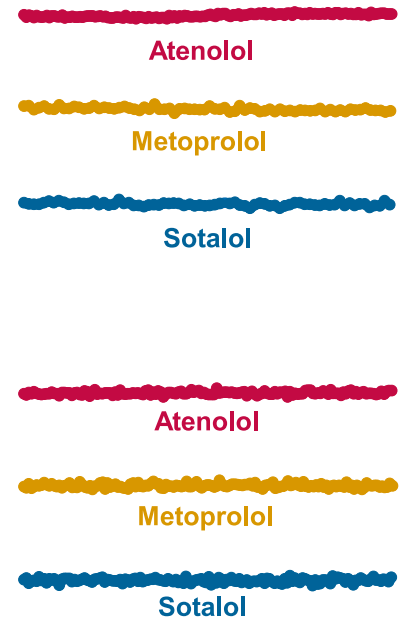

Sotalol
Fig. 2. Representative traces of $\mathrm{Ca}_{\mathrm{i}}^{2+}$ release in (A) PC3 prostate cancer and (B) MCF7 breast cancer cells in response to the addition of $50 \mu \mathrm{M}$ $\beta$-blockers: propranolol (green), atenolol (magenta), metoprolol (yellow), and sotalol (blue). The $x$-axis represents time (s) and the $y$-axis represents the Fluo-4/FuraRed ratio (free calcium/bound calcium, respectively) in arbitrary units (AU). The waveform was used to calculate the kinetics (rise, dwell, and fall times) of the $\mathrm{Ca}_{\mathrm{i}}^{2+}$ release (see Fig. 5). The mean amplitude and time constants were used to select a representative trace for each compound ( $n=5-8$ experiments, $n=151-448$ single-cell measurements per $\beta$-blocker). Of the four $\beta$-blockers tested, propranolol was the only one to induce $\mathrm{Ca}_{\mathrm{i}}^{2+}$ release in both PC3 and MCF7 cell lines.

concentrations that we tested. The representative currentvoltage (I-V) curves are shown in Fig. 8E. These results indicate that endogenous currents in PC3 cells can be modulated differently by the $\beta$-blockers investigated.

\section{Discussion}

In this study, we investigated the direct activation of calcium stores by atenolol, metoprolol, propranolol, and sotalol. We have shown that $\beta$-blockers have differential characteristics of $\mathrm{Ca}_{\mathrm{i}}^{2}$ mobilization in human cancer cell lines. Propranolol activates free $\mathrm{Ca}_{\mathrm{i}}^{2+}$ release, whereas atenolol, metoprolol, and sotalol do not. We propose that CICR is a mechanism by which propranolol activates free $\mathrm{Ca}_{\mathrm{i}}^{2+}$ release from intracellular stores.
Free $\mathrm{Ca}_{\mathrm{i}}^{2+}$ is an important second messenger owing to its regulatory role of normal (Berridge et al., 2000) and malignant cell function (Prevarskaya et al., 2011). To the best of our knowledge, the regulation of $\mathrm{Ca}_{\mathrm{i}}^{2+}$ mobilization by $\beta$-blockers in cancer cells remains largely unknown (Supplemental Table 1). We found that propranolol activates the release of $\mathrm{Ca}_{\mathrm{i}}^{2+}$ from the cellular stores with distinct kinetics of rise, dwell, and fall times in both PC3 and MCF7 cancer cell lines. In comparison with previous research analyzing the kinetics of $\mathrm{Ca}_{\mathrm{i}}^{2+}$ mobilization in response to Wnt ligands (Thrasivoulou et al., 2013) and other MPRCs in clinical use (Petrou et al., 2017), the propranolol-induced $\mathrm{Ca}_{\mathrm{i}}^{2+}$ time constants (Fig. 5) suggest that this $\beta$-blocker activates a slow exhaustion and replenishment of $\mathrm{Ca}_{\mathrm{i}}^{2+}$ stores, with a short dwell time (i.e., $20 \pm 6$ seconds, mean \pm S.D. of $n=8$ imaging experiments).

The propranolol-induced $\mathrm{Ca}_{\mathrm{i}}^{2+}$ release does not follow a classic pattern. A measurable $\mathrm{Ca}_{i}^{2+}$ release (i.e., a waveform with a well time of $>15$ seconds), is observed in around $30 \%$ of cells ( $n=$ 518 cells, from $n=6$ experiments) at $35 \mu \mathrm{M}$ propranolol, a variability reflected in the box plot (Fig. 3); however, at $50 \mu \mathrm{M},>98 \%$ of cells show an increase in propranolol-induced $\mathrm{Ca}_{i}^{2+}$ release. The data suggest that activation of $\mathrm{Ca}_{i}^{2+}$ release in PC3 cells occurs between 35 and $50 \mu \mathrm{M}$ (Fig. 3) with no significant, observable response to concentrations $<35 \mu \mathrm{M}$. It should be noted that the $\mathrm{Ca}_{i}^{2+}$ release readout is not a direct assay of propranolol binding to effective receptors, which generally follows a classic Michaelis-Menten kinetics. The readout may reflect cooperativity within the numerous intermediate steps until a threshold is achieved to activate the intracellular calcium stores.

Extracellular calcium triggering CICR, an autocatalytic mechanism found in muscle (Endo, 2009) and nonmuscle cells (Verkhratsky and Shmigol, 1996; Petrou et al., 2017), is likely to be at least one of the signals that triggers the release of $\mathrm{Ca}_{\mathrm{i}}^{2}$ in response to propranolol. Our dantrolene results (Fig. 6A) suggest that type 1 and/or 3 RyRs are also likely to be involved in the calcium efflux from the ER (Zhao et al., 2001), although there are other RyRs inhibitors, such as ruthenium red (Xu et al., 1999), that we have not tested in our experiments. EGTA and dantrolene did not inhibit the propranolol-induced $\mathrm{Ca}_{\mathrm{i}}^{2+}$ release completely (Fig. $6 \mathrm{~B}$ ); this may indicate that there are other mechanisms by which stores are activated by propranolol or may be due to a partial calcium chelation and RyR inhibition by these agents.
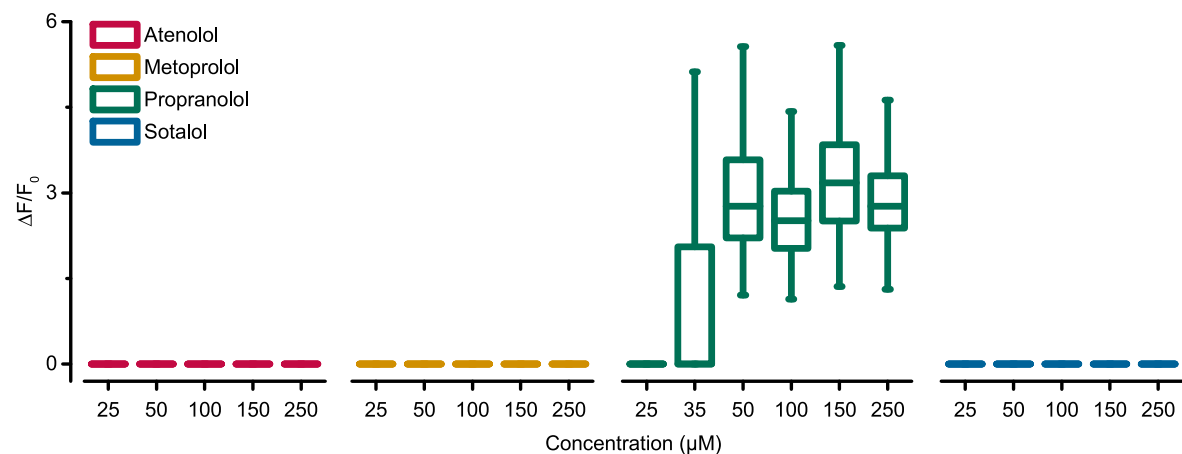

Fig. 3. Characterization of free $\mathrm{Ca}_{i}^{2+}$ release in response to various concentrations of $\beta$-blockers in PC3 cells. PC3 prostate cancer cells loaded with the calcium indicators Fluo-4 and FuraRed were treated with $\beta$-blockers, added as a bolus into the FluoroDish, and monitored over time using time-lapse confocal microscopy. $\mathrm{Ca}_{i}^{2+}$ release was measured as changes in the Fluo-4/FuraRed ratio; the amplitude of the $\mathrm{Ca}_{\mathrm{i}}^{2+}$ release was calculated as fold increase in fluorescence intensity from baseline to peak $\left(\Delta \mathrm{F} / \mathrm{F}_{0}\right)$ of the Fluo-4/FuraRed waveform and is presented as box plots. At a range of pharmacologic concentrations (see Supplemental Fig. 1 for details), only propranolol activated the release of $\mathrm{Ca}_{\mathrm{i}}^{2+}$. Other $\beta$-blockers, atenolol, metoprolol, and sotalol, did not mobilize $\mathrm{Ca}_{\mathrm{i}}^{2+}(n=107$ imaging experiments and $n=7256$ individual cells analyzed; with at least $n \geq 2$ experiments and $n>130$ cells per concentration for each $\beta$-blocker). 
A

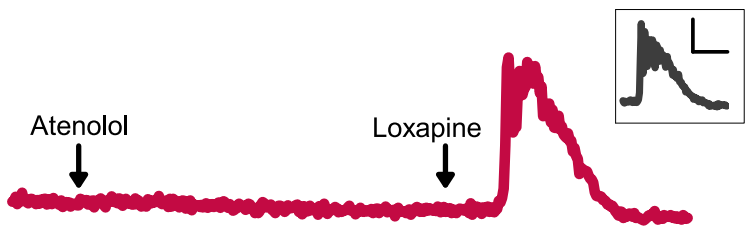

B
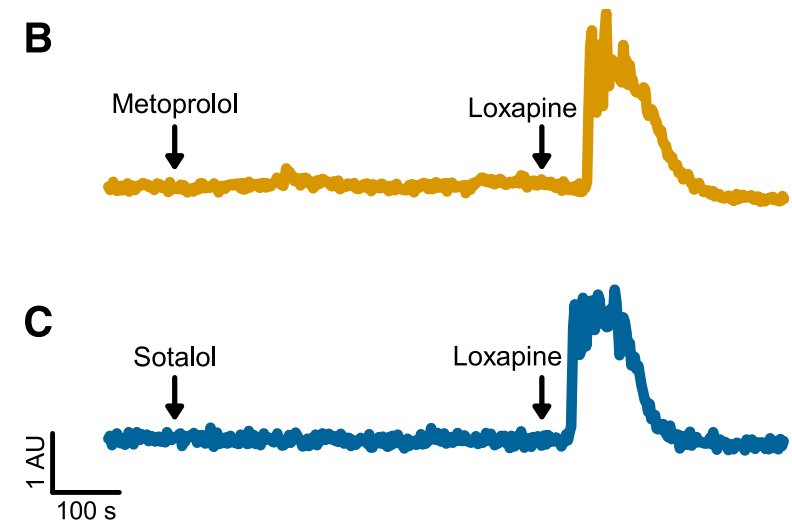

Fig. 4. Atenolol, metoprolol, and sotalol did not induce the release of $\mathrm{Ca}_{\mathrm{i}}^{2+}$ in PC3 prostate cancer or MCF7 breast cancer cells. To confirm this observation, PC3 cells loaded with the calcium indicators Fluo-4 and FuraRed were treated with $50 \mu \mathrm{M} \beta$-blocker (atenolol, metoprolol, or sotalol, added as a bolus) and after 10 minutes of imaging, the cells were treated with $50 \mu \mathrm{M}$ loxapine, a dibenzoxazepine antipsychotic drug known to activate the release of free $\mathrm{Ca}_{\mathrm{i}}^{2+}$ in human cancer cells (see Fig. 4 from Petrou et al., 2017 for details). Representative traces of $\mathrm{Ca}_{\mathrm{i}}^{2+}$ release (amplitude of the Fluo-4/FuraRed ratio over time) in response to the addition of (A) atenolol (magenta), (B) metoprolol (yellow), or (C) sotalol (blue), followed by the addition of loxapine; arrows indicate the time of addition ( $n=3$ per $\beta$-blocker, with $n=161-272$ individual cells). A representative trace of loxapine-induced $\mathrm{Ca}_{i}^{2+}$ release in control cells (no previous treatments) is shown in the insert (scale: $y$-axis 1 AU and $x$-axis 100 seconds). Note that there was no $\mathrm{Ca}_{\mathrm{i}}^{2+}$ release in response to any of the three $\beta$-blockers whereas loxapine caused an immediate release of $\mathrm{Ca}_{\mathrm{i}}^{2+}$ in the cells.

Depletion of $\mathrm{ER} \mathrm{Ca}_{\mathrm{i}}^{2+}$ with thapsigargin, which inhibits the SERCA pump (Thastrup et al., 1990), or 4-CmC, which discharges the ER via activation of RyR channels (Zorzato et al., 1993; Herrmann-Frank et al., 1996), completely abolished the $\mathrm{Ca}_{\mathrm{i}}^{2+}$ release induced by propranolol, suggesting that the ER is the main store from which calcium is released in response to this $\beta$-blocker (Fig. 6; Supplemental Fig. 3). We do not, however, exclude the possibility that other intracellular calcium stores (e.g., mitochondria) may also contribute to the propranololinduced $\mathrm{Ca}_{i}^{2+}$ release (Michelangeli et al., 2005).

These data also suggest that $\mathrm{IP}_{3}$ is involved in the propranololinduced $\mathrm{Ca}_{\mathrm{i}}^{2+}$ release. Here, 2-APB, an agent largely used as an inhibitor of $\mathrm{IP}_{3}$-induced $\mathrm{Ca}_{\mathrm{i}}^{2+}$ release (Maruyama et al., 1997; Choi et al., 2010; Saleem et al., 2014), abolished the $\mathrm{Ca}_{\mathrm{i}}^{2+}$ release activated by propranolol (Fig. 6; Supplemental Fig. 4). 2-APB is also thought to block store-operated calcium entry channels (Gregory et al., 2001), the SERCA pump (Missiaen et al., 2001), and some members of the TRP family (Xu et al., 2005; Togashi et al., 2008), although these interactions are complex (Prakriya and Lewis, 2001; Xu et al., 2005) and vary across cell types (Bootman et al., 2002). It is possible that the blockade of TRP channels may also contribute to the inhibition of the propranolol-induced $\mathrm{Ca}_{\mathrm{i}}^{2+}$ release caused by 2-APB, presuming that TRP channels may be involved in the activation of CICR pathways in response to propranolol (see later). Based on our observations, we suggest that inhibition of the propranolol-induced $\mathrm{Ca}_{\mathrm{i}}^{2+}$ release by 2-APB indicates the involvement of $\mathrm{IP}_{3}$ as an intracellular transducer that is produced upon propranolol-receptor binding and contributes to the activation of a calcium influx through $\mathrm{IP}_{3}$ receptors in the ER, in agreement with our observations using thapsigargin since $\mathrm{IP}_{3}$-responsive $\mathrm{Ca}_{\mathrm{i}}^{2+}$ pools are thapsigargin-sensitive (Tanaka and Tashjian, 1993; Tribe et al., 1994).

Class II antiarrhythmics are $\beta$-AR antagonists primarily, but they are also known to act upon potassium (Sakuta et al., 1992; Xie et al., 1998; Dupuis et al., 2005; Kawakami et al., 2006; Tamura et al., 2009) and sodium ion channels (Desaphy et al., 2003; Bankston and Kass, 2010; Wang et al., 2010a) (Supplemental Table 2). I-V curves of whole-cell patch-clamp recordings (Fig. 8E) showed the characteristics of an outward rectifying $\mathrm{K}^{+}$current, a current that has been previously described for PC3 cells (Laniado et al., 2001). Propranolol inhibits these endogenous currents similarly to those described for antiarrhythmic MPRCs, such as dofetilide (Petrou et al., 2017). At low concentrations (between 0.04 and $8.4 \mu \mathrm{M}$ ), there is an increase in the inward and outward currents, which are inhibited at higher concentrations $(>56 \mu \mathrm{M})$. In view of the absence of a measurable $\mathrm{Ca}_{2+\mathrm{i}}$ release at $<35 \mu \mathrm{M}$ propranolol, we speculate that this observation may reflect differences in the experimental design in which drugs are applied to the bath as a bolus for $\mathrm{Ca}_{\mathrm{i}}^{2+}$ imaging compared with rapid microfluidic application in the QPatch recordings. The amplitude of the propranolol-induced $\mathrm{Ca}_{\mathrm{i}}{ }^{2+}$ release plateaus between 50 and $250 \mu \mathrm{M}$ propranolol (Fig. 3), indicating that once the threshold concentration of $50 \mu \mathrm{M}$ propranolol is reached, the $\mathrm{Ca}_{\mathrm{i}}^{2+}$ stores are activated. The $50 \mu \mathrm{M}$ propranolol is an order of magnitude greater than the concentration at which cell membrane currents are activated by propranolol (Fig. 8C). We have previously suggested that there may be a small number of
A

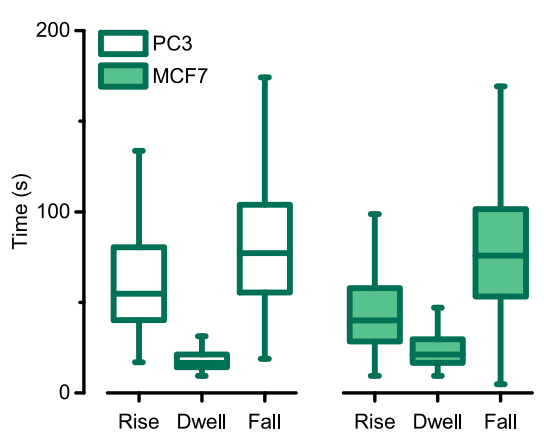

B

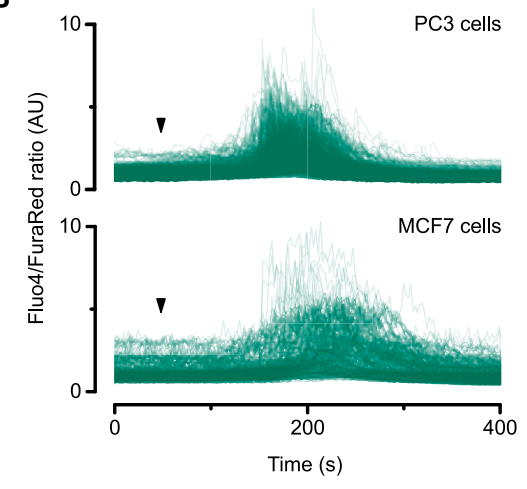

Fig. 5. Characterization of the propranolol-induced $\mathrm{Ca}_{\mathrm{i}}^{2+}$ release kinetics in PC3 prostate cancer and MCF7 breast cancer cells. (A) The $\mathrm{Ca}_{i}^{2+}$ waveform generated by the addition of $50 \mu \mathrm{M}$ propranolol to PC3 or MCF7 cells was defined by three time constants: rise, dwell, and fall times, represented as box plots $(n=5-8$ imaging experiments per cell line, with $n=151-448$ single cell measurements). The $\mathrm{Ca}_{\mathrm{i}}^{2+}$ release activated by propranolol had comparable time constants in both cancer cell lines. (B) Superimposed traces for individual cells of the propranolol-induced $\mathrm{Ca}_{\mathrm{i}}^{2+}$ release in PC3 and MCF7 cell lines; arrowheads indicate the time of propranolol addition to the cells. 
A

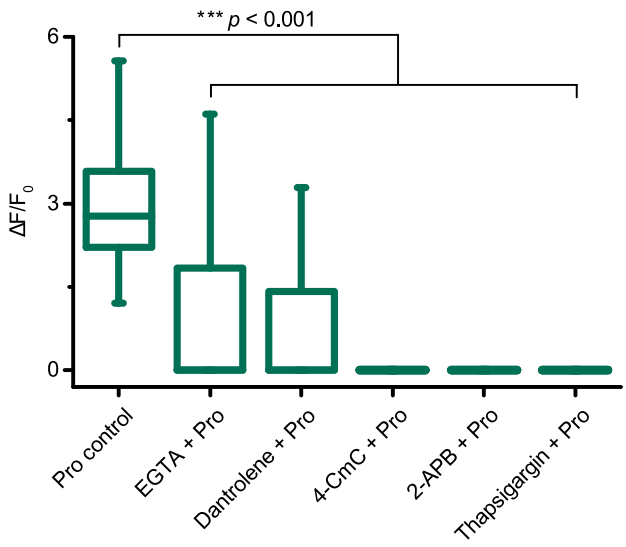

B
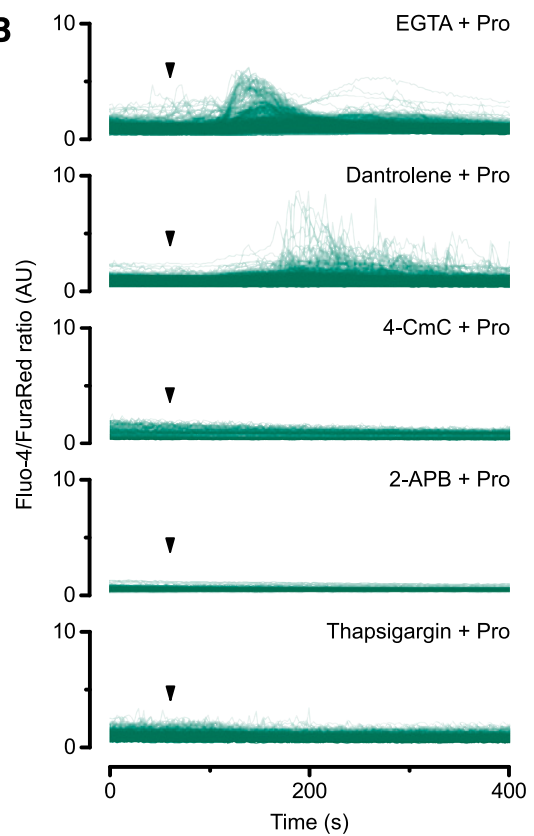

Fig. 6. Calcium-induced calcium release (CICR) as a putative mechanism for the propranolol-induced $\mathrm{Ca}_{\mathrm{i}}^{2+}$ release. $\mathrm{PC} 3$ cells were treated with $50 \mu \mathrm{M}$ propranolol (Pro; added as a bolus) and different chelators or inhibitors of CICR pathways; the mobilization of free $\mathrm{Ca}_{i}^{2+}$ release was monitored by timelapse confocal microscopy. (A) Amplitude of the propranolol-induced $\mathrm{Ca}_{\mathrm{i}}^{2+}$ release, calculated as fold increase in the fluorescence intensity of the calcium waveform $\left(\Delta \mathrm{F} / \mathrm{F}_{0}\right)$. Box plots $(\mathrm{L}-\mathrm{R})$ : 1) control cells treated with propranolol only, 2) EGTA $5 \mathrm{mM}$ (chelation of extracellular calcium), 3) dantrolene $10 \mu \mathrm{M}$ (inhibition of the ER RyR channels), 4) 4-CmC $1 \mathrm{mM}$ (depletion of ER stores via activation of RyR channels), 5) 2-APB $50 \mu \mathrm{M}$ (inhibition of the ER IP receptor channels), and 6) thapsigargin $5 \mu \mathrm{M}$ (exhaustion of ER stores via inhibition of SERCA pump). Blocking CICR pathways significantly inhibited the propranolol-induced $\mathrm{Ca}_{\mathrm{i}}^{2+}$ release (Mann-Whitney $U$ Test, ${ }^{* * *} P<0.001 ; n=3-8$ imaging experiments and $n=186-575$ single-cell measurements per condition). (B) Superimposed traces for individual cells of the propranolol-induced $\mathrm{Ca}_{\mathrm{i}}^{2+}$ release after EGTA, dantrolene, 4-CmC, 2-APB, or thapsigargin; the time of propranolol addition is indicated by arrowheads. A representative trace for propranolol-induced $\mathrm{Ca}_{\mathrm{i}}^{2+}$ release can be found in Fig. $2 \mathrm{~A}$

TRP channels $(\sim 100$ channels, calculated based on the conductance of control cells' inward currents; Petrou et al., 2017) that may be responsible for the calcium influx required for the activation of $\mathrm{Ca}_{\mathrm{i}}^{2+}$ stores, and this may also be the case for propranolol. It is also plausible that there may be independent inhibition of whole-cell currents (based on the multiple
A

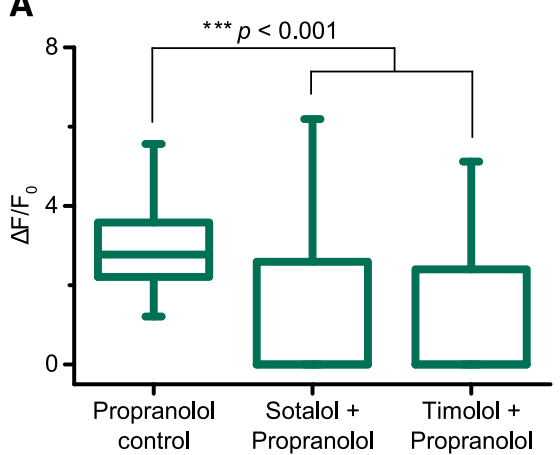

B

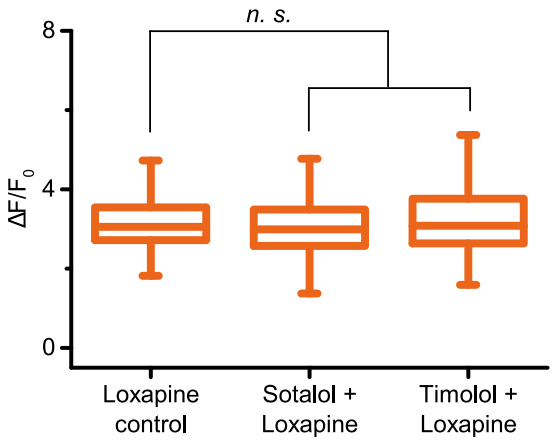

C
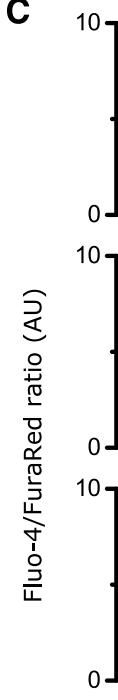

\rfloor
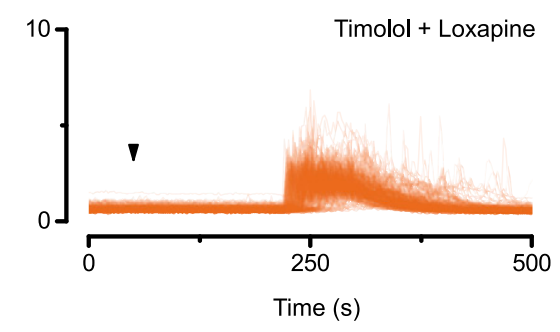

Fig. 7. Preincubation with nonselective $\beta$-blockers precludes normal propranololinduced $\mathrm{Ca}_{\mathrm{i}}^{2+}$ release. (A) PC3 cells were loaded with the calcium indicators Fluo-4 and FuraRed, as in previous experiments. Cells were pretreated with $250 \mu \mathrm{M}$ of either sotalol or timolol (added as a bolus), nonselective $\beta$-blockers used to block the $\beta$-ARs. After 2 minutes of incubation, $50 \mu \mathrm{M}$ propranolol was added to the cells, and intracellular calcium levels were monitored over time. Sotalol and timolol significantly inhibited the propranololinduced $\mathrm{Ca}_{\mathrm{i}}^{2+}$ release. (B) Control experiments were performed likewise using loxapine, a drug from a different pharmacologic class (i.e., dibenzoxazepine) that is known to activate $\mathrm{Ca}_{i}^{2+}$ release in these cells (Petrou et al., 2017). The loxapine-induced $\mathrm{Ca}_{\mathrm{i}}^{2+}$ release was not affected by the blockade of $\beta$-ARs with sotalol or timolol $(n=3-5$ experiments and $n=191-441$ individual cells per condition; Mann-Whitney $U$ Test, ${ }^{* * *} P<0.001$, n.s., nonsignificant). (C) Superimposed traces for individual cells of the propranolol- and loxapine-induced $\mathrm{Ca}_{\mathrm{i}}^{2+}$ release after sotalol and timolol incubation; the time of propranolol or loxapine addition is indicated by arrowheads. Representative $\mathrm{Ca}_{i}^{2+}$ release traces are shown in Fig. 2A for propranolol and Fig. 4 insert for loxapine. 
A

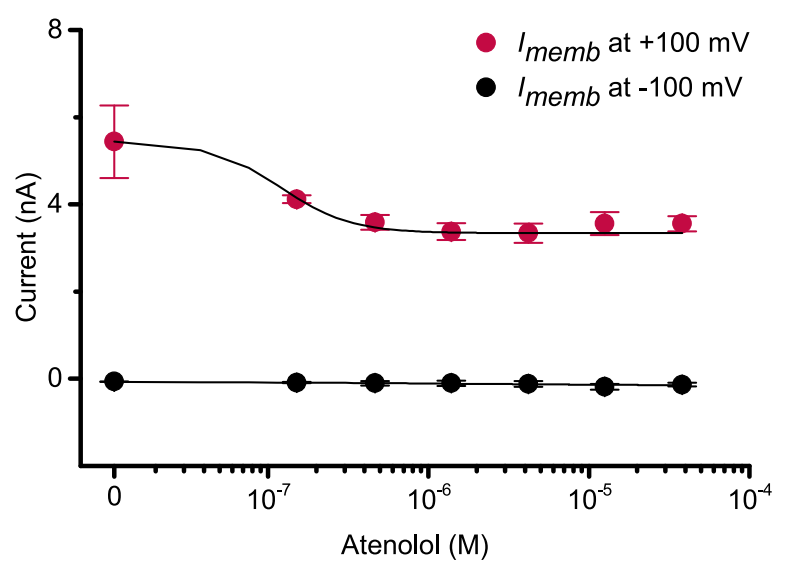

C

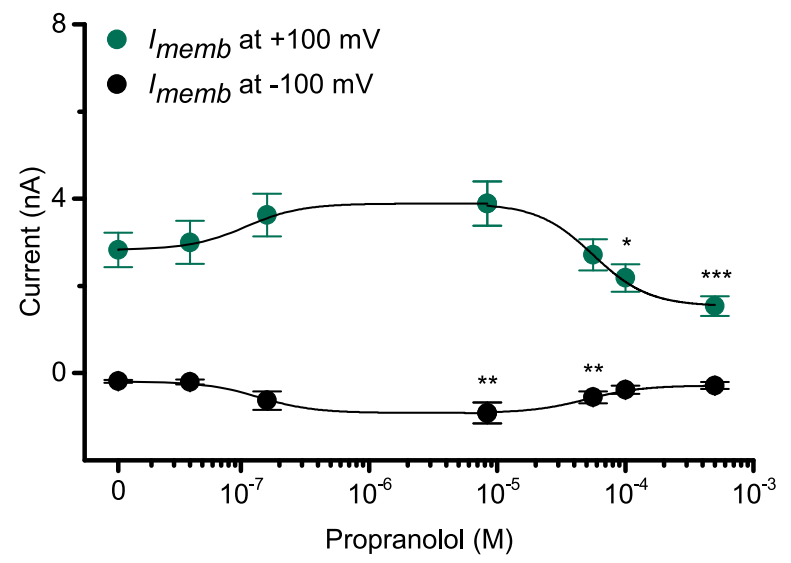

E

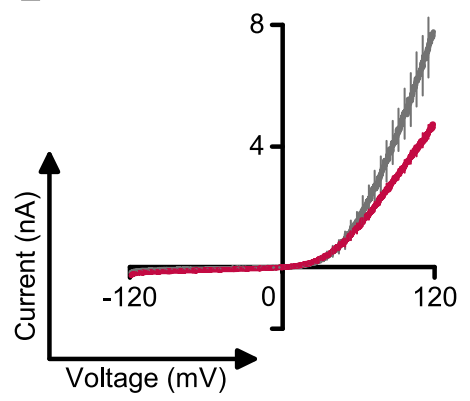

B

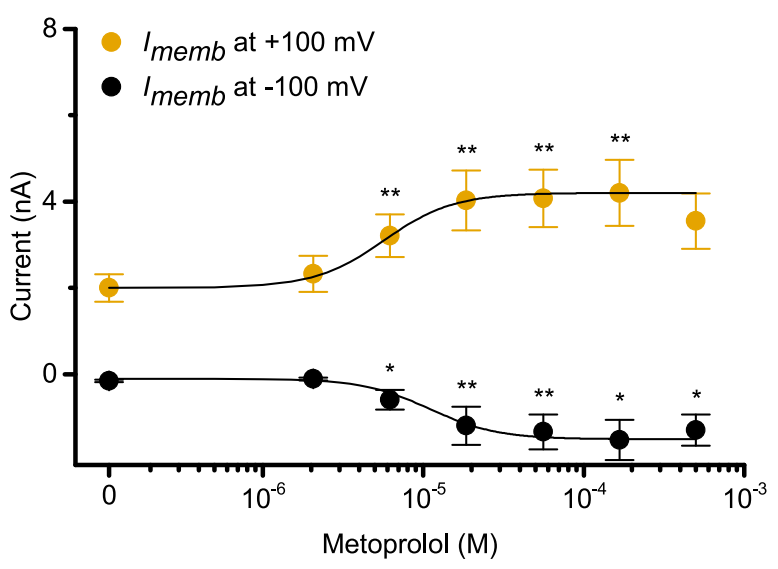

D
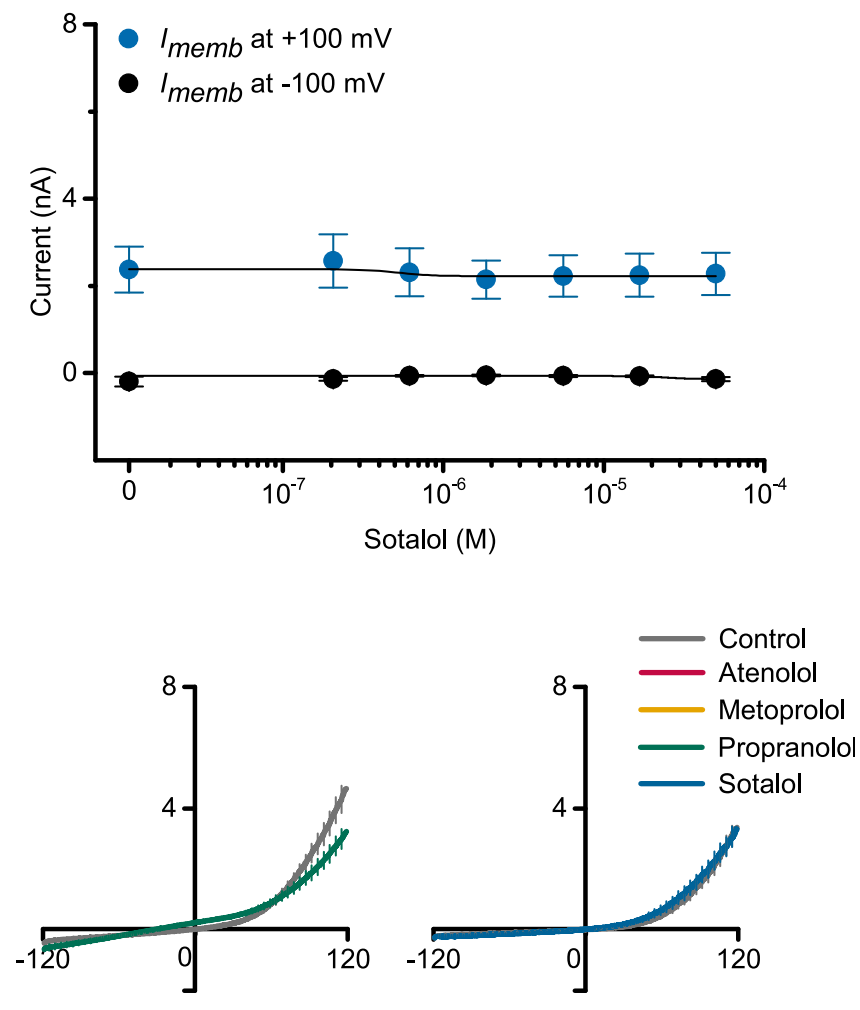

Fig. 8. $\beta$-Blocker regulation of endogenous whole-cell currents in PC3 cells. Single cells were recorded under whole-cell configuration using the QPatch automated cell patch-clamp system, which implements microfluidic control of drug delivery. (A-D) Endogenous whole-cell currents were measured by adding an increasing concentration (0-500 $\mu \mathrm{M}$, with solution changes within 500 milliseconds) of each $\beta$-blocker to the same cell clamped at a $V_{\mathrm{h}}$ of $-10 \mathrm{mV}$ and voltage ramped from -120 to $+120 \mathrm{mV}$ every 3 seconds. Currents at +100 and $-100 \mathrm{mV}$ were measured with or without $\beta$-blockers at six different concentrations and are shown as mean \pm S.E.M. $(n=5-19$ single cells per $\beta$-blocker $)$. Changes in cell currents with respect to control $(0 \mu \mathrm{M})$ were analyzed using the Wilcoxon test; only significant changes are indicated $\left({ }^{*} P<0.05 ; * * P<0.01 ; * * * P<0.001\right)$. (A) Atenolol, (B) metoprolol, (C) propranolol, and (D) sotalol. (E) Representative current-voltage (I-V) curves of control (gray lines) and with $\beta$-blockers (colored lines): atenolol at $38 \mu \mathrm{M}$ (magenta), metoprolol at $56 \mu \mathrm{M}$ (yellow), propranolol at $100 \mu \mathrm{M}$ (green), and sotalol at $50 \mu \mathrm{M}$ (blue) $(n=5-30$ cells; mean \pm S.E.M.).

interactions of propranolol with sodium and potassium ion channels; Supplemental Table 2), as well as an interdependent CICR-mediated mechanism of $\mathrm{Ca}_{i}^{2+}$ release. Such cellular functions for a commonly used antiarrhythmic agent may have implications on the pharmacology of this drug.

The addition of neither sotalol, which did not alter the endogenous whole-cell currents, nor metoprolol, which conversely activated these currents, led to no increase in $\mathrm{Ca}_{\mathrm{i}}^{2+}$ release. We speculate that atenolol, which does inhibit the endogenous currents but also does not activate $\mathrm{Ca}_{i}^{2+}$ release, may not be able to activate the downstream $\mathrm{IP}_{3}$ pathway. The electrophysiological properties described here represent only a beginning of what appears to be intricate and complicated mechanisms regulating intracellular signals transduced by these drugs. Our results give 


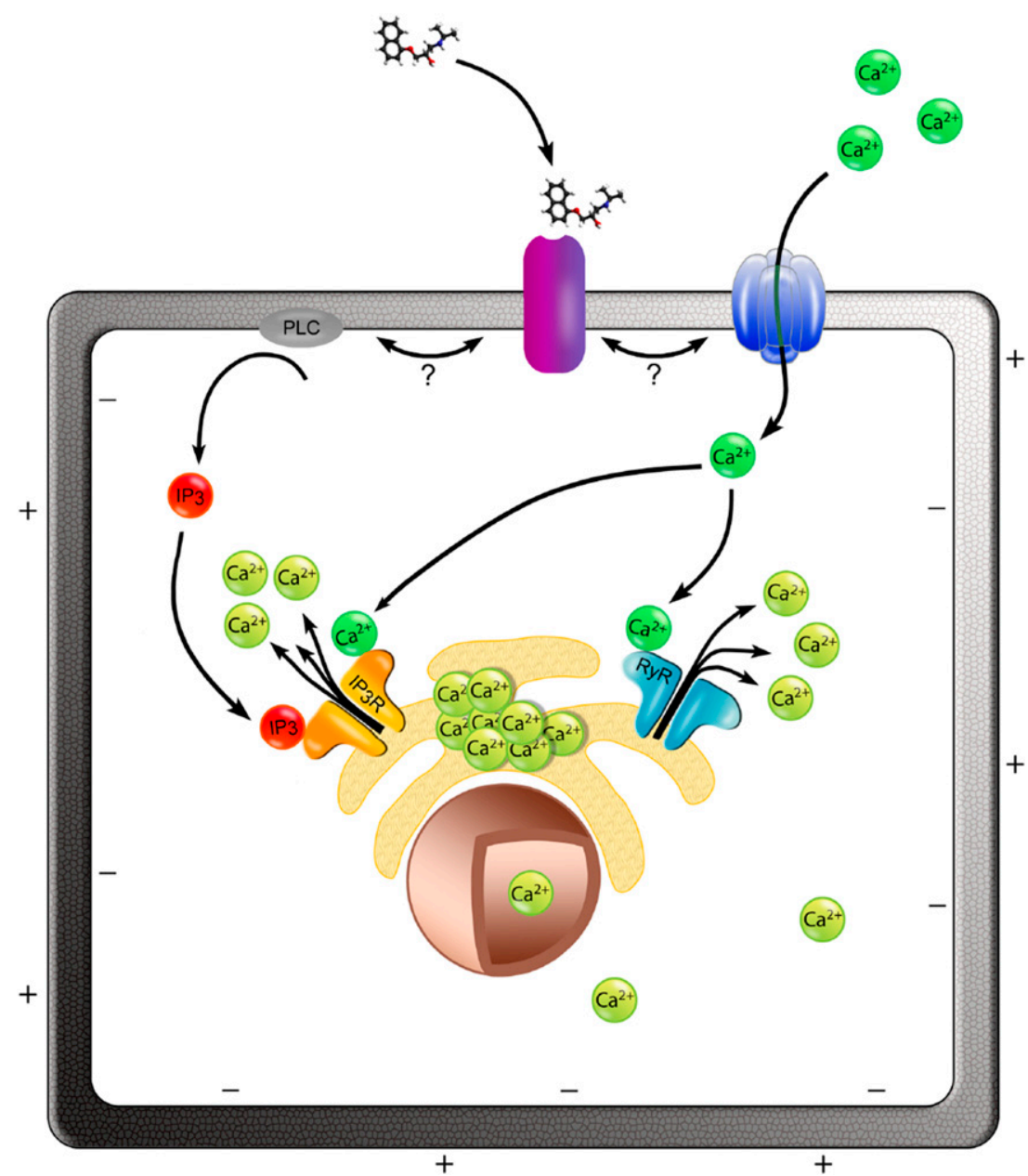

Fig. 9. Proposed model for the activation of $\mathrm{Ca}_{\mathrm{i}}^{2+}$ release by propranolol via a CICR-facilitated mechanism. We propose that the binding of propranolol to its receptor in the cell membrane (purple) triggers the downstream activation of $\mathrm{Ca}^{2+}$ release from cellular stores (e.g., the ER depicted in the model). Extracellular calcium (dark green) contributes to the propranololinduced $\mathrm{Ca}_{\mathrm{i}}^{2+}$ release; small extracellular calcium influx may enter the cell via a calcium channel or a permeable cation channel (dark blue), which is activated by propranolol-receptor binding. Extracellular calcium promotes the release of $\mathrm{Ca}_{i}^{2+}$ from ER via RyRs (light blue). Additionally, propranolol-receptor binding results in the production of $\mathrm{IP}_{3}$ (red) through the phospholipase C (PLC; gray), and this initiates a $\mathrm{Ca}_{\mathrm{i}}^{2+}$ efflux via the $\mathrm{IP}_{3}$ receptors $\left(\mathrm{IP}_{3} \mathrm{R}\right.$; orange) present in the ER surface. Once released, the free cytosolic calcium (light green) can enter the nucleus depolarizing the nuclear envelope. an interesting first insight into how $\beta$-blockers might alter the electrical properties of nonexcitable cells, although their effects are complex and require further investigation.

Excitable and nonexcitable cells are thought to have different cell electrical properties but similar intracellular calcium signaling mechanisms (Putney, 1993). The pharmacology of $\beta$-blockers is often linked to the regulation of intracellular calcium, most notably in cardiac cells (Weiss et al., 2013). Our observation that $\beta$-blockers regulate $\mathrm{Ca}_{\mathrm{i}}^{2+}$ release differently may reveal new mechanistic aspects of the action of these compounds. Atenolol and metoprolol, for example, are used mostly as antianginal and antihypertensive drugs; propranolol has a wider spectrum of applications besides its cardiovascular use (Joint Formulary Committee, 2017), such as the treatment of essential tremor (Zesiewicz et al., 2002) or anxiety (Steenen et al., 2016). Furthermore, if activation of $\mathrm{Ca}_{\mathrm{i}}^{2+}$ stores by propranolol is initiated via the $\beta_{2}$-AR (see later), this may imply that other tissues expressing this receptor, such as the lungs or blood vessels (Daly and McGrath, 2011), may undergo $\mathrm{Ca}_{\mathrm{i}}^{2+}$ release events similar to those described in the cell lines used in this study.

Based on the data presented in our study, we propose a model of action for propranolol acting on intracellular calcium stores via a CICR-facilitated mechanism. Extracellular calcium contributes to the opening of the stores and the release of calcium through RyRs, and $\mathrm{IP}_{3}$ acts as an intracellular transducer for the activation of $\mathrm{Ca}_{\mathrm{i}}^{2+}$ release from the ER (Fig. 9).
Our observation that the $\beta_{2}$-AR is the main subtype in PC3 cells at the gene expression level (Supplemental Table 3), as has been reported in human prostate tissue (Goepel et al., 1997; Suzuki et al., 2016) and other prostate cancer cell lines (Nagmani et al., 2003; Kasbohm et al., 2005), suggests that propranolol may be exerting its function via this receptor. This suggestion is supported by the observation that blockade of $\beta$-ARs with the nonselective $\beta$-blockers sotalol and timolol (Baker, 2005) inhibited the propranolol-induced $\mathrm{Ca}_{\mathrm{i}}^{2+}$ release (Fig. 7), although this could also be attributed to nonselective cellular targets common to sotalol, timolol, and propranolol (Supplemental Table 2). MCF7 cells also express $\beta$-ARs (Supplemental Table 3; Shi et al., 2011; Işeri et al., 2014); even if the expression of the $\beta$-ARs is not as high in MCF7 cells as in other breast cancer cell lines (Vandewalle et al., 1990), radioligand binding assays have estimated that there are $\sim 80,000$ binding sites per cell in MCF7 cells (Gargiulo et al., 2014).

In the model we propose (Fig. 9), binding of propranolol to its receptor may activate extracellular calcium entry, which can trigger store-operated calcium release via CICR. Routes for calcium entry can include specific calcium channels as well as nonspecific cation channels that have significant calcium permeability, such as members of the TRP family (Clapham et al., 2001), some of which are known to be expressed in cancer cells (Bödding, 2007), including prostate cancer (Wissenbach et al., 2004; Bidaux et al., 2007; Prevarskaya et al., 2007). The focus of our future studies will be to 
investigate the receptors, ion channels, and downstream pathways responsible for the propranolol-induced $\mathrm{Ca}_{\mathrm{i}}^{2+}$ release described here and examine the effects in the transcriptional profile of cancer cells.

Propranolol is known to inhibit cell migration in several in vitro and in vivo models of cancer, including breast (Campbell et al., 2012; Işeri et al., 2014; Pon et al., 2016), colon (Masur et al., 2001; Işeri et al., 2014), angiosarcoma (Stiles et al., 2013), and prostate cancer (Palm et al., 2006). Free $\mathrm{Ca}_{\mathrm{i}}^{2+}$ is an important regulator of tumor metastasis, and several $\mathrm{Ca}^{2+}$-dependent mechanisms contribute to malignant cell migration (Prevarskaya et al., 2011). Propranolol has shown greater antimigratory effects than other $\beta$-blockers, such as atenolol (Masur et al., 2001; Işeri et al., 2014). In cancer cell lines, including PC3 cells, propranolol (between 100 and $200 \mu \mathrm{M}$ ) was shown to inhibit proliferation and induce apoptosis (Zhang et al., 2010; Brohée et al., 2015; Coelho et al., 2015; Wrobel and Le Gal, 2015; Chin et al., 2016; Wei et al., 2016; reviewed in Pantziarka et al., 2016). The concentration at which propranolol exerted these antiproliferative and proapoptotic effects is within the range at which we observe propranolol-induced $\mathrm{Ca}_{\mathrm{i}}^{2+}$ release in PC3 and MCF7 cells. It is also notable that in the same studies (Zhang et al., 2010; Coelho et al., 2015; Wrobel and Le Gal, 2015; Chin et al., 2016; Wei et al., 2016) neither atenolol nor metoprolol inhibited cell proliferation or induced apoptosis.

Our results point to a novel action of propranolol and its potential as a regulator of the magnitude and duration of $\mathrm{Ca}_{\mathrm{i}}^{2+}$ release in vitro. Our finding that propranolol mobilizes free $\mathrm{Ca}_{\mathrm{i}}^{2+}$, which distinguishes this drug from other commonly used $\beta$-blockers, opens new possibilities into how propranolol may contribute to the inhibition of malignant cell migration and proliferation, whereas other $\beta$-blockers that do not activate $\mathrm{Ca}_{\mathrm{i}}^{2+}$ release may not exert the same effect. This mechanism may thus be relevant patients who are treated with these drugs (Baker et al., 2011; Pantziarka et al., 2016).

\section{Acknowledgments}

We thank Jane Pendjiky, University College London, for help with the preparation of Fig. 9.

\section{Authorship Contributions}

Participated in research design: Ahmed, Reyes-Corral, Sørensen. Conducted experiments: Reyes-Corral, Sørensen.

Contributed to new reagents or analytical tools: Thrasivoulou, Dasgupta, Ashmore.

Performed data analysis: Reyes-Corral, Sørensen, Ashmore, Ahmed. Wrote or contributed to the writing of the manuscript: Reyes-Corral, Ashmore, Ahmed.

\section{References}

Baker JG (2005) The selectivity of $\beta$-adrenoceptor antagonists at the human $\beta 1, \beta 2$ and $\beta 3$ adrenoceptors. Br J Pharmacol 144:317-322.

Baker JG, Hill SJ, and Summers RJ (2011) Evolution of $\beta$-blockers: from anti-anginal drugs to ligand-directed signalling. Trends Pharmacol Sci 32:227-234.

Bankston JR and Kass RS (2010) Molecular determinants of local anesthetic action of beta-blocking drugs: implications for therapeutic management of long QT syndrome variant 3. J Mol Cell Cardiol 48:246-253.

Barron TI, Connolly RM, Sharp L, Bennett K, and Visvanathan K (2011) Beta blockers and breast cancer mortality: a population- based study. J Clin Oncol 29:2635-2644.

Baumgart P, Zidek W, Schmidt W, Haecker W, Dorst KG, and Vetter H (1986) Intracellular calcium in hypertension: effect of treatment with $\beta$-adrenoreceptor blockers. J Cardiovasc Pharmacol 8:559-561.

Berridge MJ, Bootman MD, and Roderick HL (2003) Calcium signalling: dynamics, homeostasis and remodelling. Nat Rev Mol Cell Biol 4:517-529.

Berridge MJ, Lipp P, and Bootman MD (2000) The versatility and universality of calcium signalling. Nat Rev Mol Cell Biol 1:11-21.

Bidaux G, Flourakis M, Thebault S, Zholos A, Beck B, Gkika D, Roudbaraki M, Bonnal JL, Mauroy B, Shuba Y, et al. (2007) Prostate cell differentiation status determines transient receptor potential melastatin member 8 channel subcellular localization and function. $J$ Clin Invest 117:1647-1657.

Black JW, Crowther AF, Shanks RG, Smith LH, and Dornhorst AC (1964) A new adrenergic betareceptor antagonist. Lancet 1:1080-1081.

Bödding M (2007) TRP proteins and cancer. Cell Signal 19:617-624.

Bootman MD, Collins TJ, Mackenzie L, Roderick HL, Berridge MJ, and Peppiatt CM (2002) 2-Aminoethoxydiphenyl borate (2-APB) is a reliable blocker of storeoperated $\mathrm{Ca}^{2+}$ entry but an inconsistent inhibitor of $\mathrm{InsP}_{3}$-induced $\mathrm{Ca}^{2+}$ release. FASEB J 16:1145-1150.

Brohée L, Demine S, Willems J, Arnould T, Colige AC, and Deroanne CF (2015) Lipin-1 regulates cancer cell phenotype and is a potential target to potentiate rapamycin treatment. Oncotarget 6:11264-11280.

Campbell JP, Karolak MR, Ma Y, Perrien DS, Masood-Campbell SK, Penner NL, Munoz SA, Zijlstra A, Yang X, Sterling JA, et al. (2012) Stimulation of host bone marrow stromal cells by sympathetic nerves promotes breast cancer bone metastasis in mice. PLoS Biol 10:e1001363.

Carafoli E, Santella L, Branca D, and Brini M (2001) Generation, control, and processing of cellular calcium signals. Crit Rev Biochem Mol Biol 36:107-260.

Cekic EG, Soydan G, Guler S, Babaoglu MO, and Tuncer M (2013) Propranololinduced relaxation in the rat basilar artery. Vascul Pharmacol 58:307-312.

Chin CC, Li JM, Lee KF, Huang YC, Wang KC, Lai HC, Cheng CC, Kuo YH, and Shi CS (2016) Selective $\beta 2$-AR blockage suppresses colorectal cancer growth through regulation of EGFR-Akt/ERK1/2 signaling, G1-phase arrest, and apoptosis. $J$ Cell Physiol 231:459-472.

Chobanian AV, Bakris GL, Black HR, Cushman WC, Green LA, Izzo JL Jr, Jones DW, Materson BJ, Oparil S, Wright JT Jr, et al. National Heart, Lung, and Blood Institute Joint National Committee on Prevention, Detection, Evaluation, and Treatment of High Blood Pressure National High Blood Pressure Education Program Coordinating Committee (2003) The seventh report of the Joint National Committee on prevention, detection, evaluation, and treatment of high blood pressure: the JNC 7 report. JAMA 289:2560-2572.

Choi KJ, Kim KS, Kim SH, Kim DK, and Park HS (2010) Caffeine and 2 -aminoethoxydiphenyl borate (2-APB) have different ability to inhibit intracellular calcium mobilization in pancreatic acinar cell. Korean J Physiol Pharmacol 14:105-111.

Clapham DE, Runnels LW, and Strübing C (2001) The TRP ion channel family. Nat Rev Neurosci 2:387-396.

Coelho M, Moz M, Correia G, Teixeira A, Medeiros R, and Ribeiro L (2015) Antiproliferative effects of $\beta$-blockers on human colorectal cancer cells. Oncol Rep 33:2513-2520.

Cole SW and Sood AK (2012) Molecular pathways: beta-adrenergic signaling in cancer. Clin Cancer Res 18:1201-1206.

Cseplo P, Vamos Z, Ivic I, Torok O, Toth A, and Koller A (2016) The beta-1-receptor blocker nebivolol elicits dilation of cerebral arteries by reducing smooth muscle $\left[\mathrm{Ca}^{2+}\right]_{\mathrm{i}}$. PLoS One 11:e 0164010.

Daly CJ and McGrath JC (2011) Previously unsuspected widespread cellular and tissue distribution of $\beta$-adrenoceptors and its relevance to drug action. Trends Pharmacol Sci 32:219-226.

De Giorgi V, Grazzini M, Benemei S, Marchionni N, Geppetti P, and Gandini S (2017) $\beta$-Blocker use and reduced disease progression in patients with thick melanoma: 8 years of follow-up. Melanoma Res 27:268-270.

De Giorgi V, Grazzini M, Gandini S, Benemei S, Lotti T, Marchionni N, and Geppetti $P(2011)$ Treatment with $\beta$-blockers and reduced disease progression in patients with thick melanoma. Arch Intern Med 171:779-781.

Desaphy JF, Pierno S, De Luca A, Didonna P, and Camerino DC (2003) Different ability of clenbuterol and salbutamol to block sodium channels predicts their therapeutic use in muscle excitability disorders. Mol Pharmacol 63:659-670.

Doi M, Yano M, Kobayashi S, Kohno M, Tokuhisa T, Okuda S, Suetsugu M, Hisamatsu Y, Ohkusa T, Kohno M, et al. (2002) Propranolol prevents the development of heart failure by restoring FKBP12.6-mediated stabilization of ryanodine receptor. Circulation 105:1374-1379.

Dupuis DS, Klaerke DA, and Olesen SP (2005) Effect of $\beta$-adrenoceptor blockers on human ether-a-go-go-related gene (HERG) potassium channels. Basic Clin Pharmacol Toxicol 96:123-130.

Endo M (2009) Calcium-induced calcium release in skeletal muscle. Physiol Rev 89: 1153-1176.

Erne P, Bolli P, Bürgisser E, and Bühler FR (1984) Correlation of platelet calcium with blood pressure Effect of antihypertensive therapy. $N$ Engl $J$ Med 310 : $1084-1088$

Gargiulo L, Copsel S, Rivero EM, Galés C, Sénard JM, Lüthy IA, Davio C, and Bruzzone A (2014) Differential $\beta_{2}$-adrenergic receptor expression defines the phenotype of non-tumorigenic and malignant human breast cell lines. Oncotarget 5:10058-10069.

Goepel M, Wittmann A, Rübben H, and Michel MC (1997) Comparison of adrenoceptor subtype expression in porcine and human bladder and prostate. Urol Res $\mathbf{2 5}$ : 199-206.

Gregory RB, Rychkov G, and Barritt GJ (2001) Evidence that 2-aminoethyl diphenylborate is a novel inhibitor of store-operated $\mathrm{Ca}^{2+}$ channels in liver cells, and acts through a mechanism which does not involve inositol trisphosphate receptors. Biochem J 354:285-290.

Grytli HH, Fagerland MW, Fosså SD, Taskén KA, and Håheim LL (2013) Use of $\beta$-blockers is associated with prostate cancer-specific survival in prostate cancer patients on androgen deprivation therapy. Prostate 73:250-260.

Herrmann-Frank A, Richter M, Sarközi S, Mohr U, and Lehmann-Horn F (1996) 4-Chloro- $m$-cresol, a potent and specific activator of the skeletal muscle ryanodine receptor. Biochim Biophys Acta 1289:31-40.

Işeri ÖD, Sahin FI, Terzi YK, Yurtcu E, Erdem SR, and Sarialioglu F (2014) $\beta$-Adrenoreceptor antagonists reduce cancer cell proliferation, invasion, and migration. Pharm Biol 52:1374-1381.

Joint Formulary Committee (2017) British National Formulary, 73rd ed. BMJ Group and Pharmaceutical Press, London. 
Kasbohm EA, Guo R, Yowell CW, Bagchi G, Kelly P, Arora P, Casey PJ, and Daaka Y (2005) Androgen receptor activation by $\mathrm{G}_{\mathrm{s}}$ signaling in prostate cancer cells. J Biol Chem 280:11583-11589.

Kawakami K, Nagatomo T, Abe H, Kikuchi K, Takemasa H, Anson BD, Delisle BP, January CT, and Nakashima Y (2006) Comparison of HERG channel blocking effects of various $\beta$-blockers-implication for clinical strategy. $\mathrm{Br} J$ Pharmacol 147: $642-652$

Keller MJ, Lecuona E, Prakriya M, Cheng Y, Soberanes S, Budinger GR, and Sznajder JI (2014) Calcium release-activated calcium (CRAC) channels mediate the $\beta_{2}$-adrenergic regulation of Na,K-ATPase. FEBS Lett 588:4686-4693.

Laniado ME, Fraser SP, and Djamgoz MB (2001) Voltage-gated $\mathrm{K}^{+}$channel activity in human prostate cancer cell lines of markedly different metastatic potential: distinguishing characteristics of $\mathrm{PC}-3$ and LNCaP cells. Prostate 46: $262-274$.

Lemeshow S, Sørensen HT, Phillips G, Yang EV, Antonsen S, Riis AH, Lesinski GB Jackson R, and Glaser R (2011) $\beta$-Blockers and survival among Danish patients with malignant melanoma: a population-based cohort study. Cancer Epidemiol Biomarkers Prev 20:2273-2279.

Maruyama T, Kanaji T, Nakade S, Kanno T, and Mikoshiba K (1997) 2APB, 2 -aminoethoxydiphenyl borate, a membrane-penetrable modulator of $\operatorname{Ins}(1,4,5) \mathrm{P}_{3}$ induced $\mathrm{Ca}^{2+}$ release. J Biochem 122:498-505.

Masur K, Niggemann B, Zanker KS, and Entschladen F (2001) Norepinephrineinduced migration of SW 480 colon carcinoma cells is inhibited by $\beta$-blockers. Cancer Res 61:2866-2869.

Melhem-Bertrandt A, Chavez-Macgregor M, Lei X, Brown EN, Lee RT, MericBernstam F, Sood AK, Conzen SD, Hortobagyi GN, and Gonzalez-Angulo AM (2011) $\beta$-blocker use is associated with improved relapse-free survival in patients with triple-negative breast cancer. J Clin Oncol 29:2645-2652.

Michelangeli F, Ogunbayo OA, and Wootton LL (2005) A plethora of interacting organellar $\mathrm{Ca}^{2+}$ stores. Curr Opin Cell Biol 17:135-140.

Missiaen L, Callewaert G, De Smedt H, and Parys JB (2001) 2-Aminoethoxydiphenyl borate affects the inositol 1,4,5-trisphosphate receptor, the intracellular $\mathrm{Ca}^{2+}$ pump and the non-specific $\mathrm{Ca}^{2+}$ leak from the non-mitochondrial $\mathrm{Ca}^{2+}$ stores in permeabilized A7r5 cells. Cell Calcium 29:111-116.

Naga Prasad SV, Nienaber J, and Rockman HA (2001) $\beta$-Adrenergic axis and heart disease. Trends Genet 17:S44-S49.

Nagmani R, Pasco DS, Salas RD, and Feller DR (2003) Evaluation of $\beta$-adrenergic receptor subtypes in the human prostate cancer cell line-LNCaP. Biochem Pharmacol 65:1489-1494.

Nixon GF, Mignery GA, and Somlyo AV (1994) Immunogold localization of inositol 1,4,5-trisphosphate receptors and characterization of ultrastructural features of the sarcoplasmic reticulum in phasic and tonic smooth muscle. J Muscle Res Cell Motil 15:682-700.

Palm D, Lang K, Niggemann B, Drell TL IV, Masur K, Zaenker KS, and Entschladen F (2006) The norepinephrine-driven metastasis development of PC-3 human prostate cancer cells in BALB/c nude mice is inhibited by $\beta$-blockers. Int $J$ Cancer 118:2744-2749.

Pantziarka P, Bouche G, Sukhatme V, Meheus L, Rooman I, and Sukhatme VP (2016) Repurposing Drugs in Oncology (ReDO)-Propranolol as an anti-cancer agent. Ecancermedicalscience 10:680

Perron L, Bairati I, Harel F, and Meyer F (2004) Antihypertensive drug use and the risk of prostate cancer (Canada). Cancer Causes Control 15:535-541.

Petrou T, Olsen HL, Thrasivoulou C, Masters JR, Ashmore JF, and Ahmed A (2017) Intracellular calcium mobilization in response to ion channel regulators via a calcium-induced calcium release mechanism. J Pharmacol Exp Ther 360:378-387.

Pon CK, Lane JR, Sloan EK, and Halls ML (2016) The $\beta_{2}$-adrenoceptor activates a positive cAMP-calcium feedforward loop to drive breast cancer cell invasion. FASEB J 30:1144-1154

Powe DG, Voss MJ, Zänker KS, Habashy HO, Green AR, Ellis IO, and Entschladen F (2010) Beta-blocker drug therapy reduces secondary cancer formation in breast cancer and improves cancer specific survival. Oncotarget 1:628-638.

Prakriya M and Lewis RS (2001) Potentiation and inhibition of $\mathrm{Ca}^{2+}$ releaseactivated $\mathrm{Ca}^{2+}$ channels by 2-aminoethyldiphenyl borate (2-APB) occurs independently of $\mathrm{IP}_{3}$ receptors. J Physiol 536:3-19.

Prevarskaya N, Skryma R, Bidaux G, Flourakis M, and Shuba Y (2007) Ion channels in death and differentiation of prostate cancer cells. Cell Death Differ 14:1295-1304.

Prevarskaya N, Skryma R, and Shuba Y (2011) Calcium in tumour metastasis: new roles for known actors. Nat Rev Cancer 11:609-618.

Priviero FBM, Teixeira CE, Toque HAF, Claudino MA, Webb RC, De Nucci G, Zanesco A, and Antunes E (2006) Vasorelaxing effects of propranolol in rat aorta and mesenteric artery: a role for nitric oxide and calcium entry blockade. Clin Exp Pharmacol Physiol 33:448-455.

Putney JW Jr (1993) Excitement about calcium signaling in inexcitable cells. Science 262:676-678.

Reiken S, Wehrens XHT, Vest JA, Barbone A, Klotz S, Mancini D, Burkhoff D, and Marks AR (2003) $\beta$-Blockers restore calcium release channel function and improve cardiac muscle performance in human heart failure. Circulation 107: $2459-2466$.

Sakanashi M and Takeo S (1983) Characterization of propranolol-induced relaxation of coronary artery. Jpn J Pharmacol 33:603-610.

Sakuta H, Okamoto K, and Watanabe Y (1992) Blockade by antiarrhythmic drugs of glibenclamide-sensitive $\mathrm{K}^{+}$channels in Xenopus oocytes. $\mathrm{Br} J$ Pharmacol 107: 1061-1067.

Saleem H, Tovey SC, Molinski TF, and Taylor CW (2014) Interactions of antagonists with subtypes of inositol 1,4,5-trisphosphate $\left(\mathrm{IP}_{3}\right)$ receptor. $\mathrm{Br} J$ Pharmacol 171: 3298-3312.

Shahbaz AU, Zhao T, Zhao W, Johnson PL, Ahokas RA, Bhattacharya SK, Sun Y, Gerling IC, and Weber KT (2011) Calcium and zinc dyshomeostasis during isoproterenol-induced acute stressor state. Am J Physiol Heart Circ Physiol 300: H636-H644.
Shi M, Liu D, Duan H, Qian L, Wang L, Niu L, Zhang H, Yong Z, Gong Z, Song L, et al. (2011) The $\beta_{2}$-adrenergic receptor and Her2 comprise a positive feedback loop in human breast cancer cells. Breast Cancer Res Treat 125:351-362.

Steenen SA, van Wijk AJ, van der Heijden GJ, van Westrhenen R, de Lange J, and de Jongh A (2016) Propranolol for the treatment of anxiety disorders: systematic review and meta-analysis. J Psychopharmacol 30:128-139.

Stiles JM, Amaya C, Rains S, Diaz D, Pham R, Battiste J, Modiano JF, Kokta V, Boucheron LE, Mitchell DC, et al. (2013) Targeting of beta adrenergic receptors results in therapeutic efficacy against models of hemangioendothelioma and angiosarcoma. PLoS One 8:e60021.

Suzuki T, Otsuka A, Matsumoto R, Furuse H, and Ozono S (2016) The expression of $\beta_{3}$-adrenoceptors and their function in the human prostate. Prostate $\mathbf{7 6}: 163-171$.

Tamura A, Ogura T, Uemura H, Reien Y, Kishimoto T, Nagai T, Komuro I, Miyazaki M, and Nakaya H (2009) Effects of antiarrhythmic drugs on the hyperpolarization-activated cyclic nucleotide-gated channel current. $J$ Pharmacol Sci 110:150-159.

Tanaka Y and Tashjian AH Jr (1993) Functional identification and quantitation of three intracellular calcium pools in $\mathrm{GH} 4 \mathrm{C} 1$ cells: evidence that the caffeineresponsive pool is coupled to a thapsigargin-resistant, ATP-dependent process. Biochemistry 32:12062-12073.

Thastrup O, Cullen PJ, Drøbak BK, Hanley MR, and Dawson AP (1990) Thapsigargin, a tumor promoter, discharges intracellular $\mathrm{Ca}^{2+}$ stores by specific inhibition of the endoplasmic reticulum $\mathrm{Ca}^{2+}$-ATPase. Proc Natl Acad Sci USA 87: 2466-2470.

Thrasivoulou C, Millar M, and Ahmed A (2013) Activation of intracellular calcium by multiple Wnt ligands and translocation of $\beta$-catenin into the nucleus: a convergent model of Wnt/Ca ${ }^{2+}$ and Wnt/ $\beta$-catenin pathways. J Biol Chem 288:35651-35659.

Togashi K, Inada H, and Tominaga M (2008) Inhibition of the transient receptor potential cation channel TRPM2 by 2 -aminoethoxydiphenyl borate (2-APB). $\mathrm{Br} J$ Pharmacol 153:1324-1330.

Tribe RM, Borin ML, and Blaustein MP (1994) Functionally and spatially distinct $\mathrm{Ca}^{2+}$ stores are revealed in cultured vascular smooth muscle cells. Proc Natl Acad Sci USA 91:5908-5912.

Tuncay E, Okatan EN, Vassort G, and Turan B (2013) B-Blocker timolol prevents arrhythmogenic $\mathrm{Ca}^{2+}$ release and normalizes $\mathrm{Ca}^{2+}$ and $\mathrm{Zn}^{2+}$ dyshomeostasis in hyperglycemic rat heart. PLoS One 8:e71014.

Vandewalle B, Revillion F, and Lefebvre J (1990) Functional $\beta$-adrenergic receptors in breast cancer cells. J Cancer Res Clin Oncol 116:303-306.

Verkhratsky A and Shmigol A (1996) Calcium-induced calcium release in neurones. Cell Calcium 19:1-14.

Wang DW, Mistry AM, Kahlig KM, Kearney JA, Xiang J, and George AL Jr (2010a) Propranolol blocks cardiac and neuronal voltage-gated sodium channels. Front Pharmacol 1:144

Wang Q, Symes AJ, Kane CA, Freeman A, Nariculam J, Munson P, Thrasivoulou C, Masters JR, and Ahmed A (2010b) A novel role for $\mathrm{Wnt} / \mathrm{Ca}^{2+}$ signaling in actin cytoskeleton remodeling and cell motility in prostate cancer. PLoS One 5:e10456.

Wei WJ, Shen CT, Song HJ, Qiu ZL, and Luo QY (2016) Propranolol sensitizes thyroid cancer cells to cytotoxic effect of vemurafenib. Oncol Rep 36:1576-1584.

Weiss S, Oz S, Benmocha A, and Dascal N (2013) Regulation of cardiac L-type $\mathrm{Ca}^{2+}$ channel CaVV1.2 via the $\beta$-adrenergic-cAMP-protein kinase A pathway: old dogmas, advances, and new uncertainties. Circ Res 113:617-631.

Wissenbach U, Niemeyer B, Himmerkus N, Fixemer T, Bonkhoff $\mathrm{H}$, and Flockerzi V (2004) TRPV6 and prostate cancer: cancer growth beyond the prostate correlates with increased TRPV6 $\mathrm{Ca}^{2+}$ channel expression. Biochem Biophys Res Commun 322:1359-1363

Wrobel LJ and Le Gal FA (2015) Inhibition of human melanoma growth by a noncardioselective $\beta$-blocker. J Invest Dermatol 135:525-531.

Xie LH, Takano M, and Noma A (1998) The inhibitory effect of propranolol on ATPsensitive potassium channels in neonatal rat heart. Br J Pharmacol 123:599-604.

Xu L, Tripathy A, Pasek DA, and Meissner G (1999) Ruthenium red modifies the cardiac and skeletal muscle $\mathrm{Ca}^{2+}$ release channels (ryanodine receptors) by multiple mechanisms. J Biol Chem 274:32680-32691.

Xu SZ, Zeng F, Boulay G, Grimm C, Harteneck C, and Beech DJ (2005) Block of TRPC5 channels by 2-aminoethoxydiphenyl borate: a differential, extracellular and voltage-dependent effect. Br J Pharmacol 145:405-414.

Yao A, Kohmoto O, Oyama T, Sugishita Y, Shimizu T, Harada K, Matsui H, Komuro I, Nagai R, Matsuo H, et al. (2003) Characteristic effects of $\alpha_{1}-\beta_{1,2}$-adrenergic blocking agent, carvedilol, on $\left[\mathrm{Ca}^{2+}\right]_{\mathrm{i}}$ in ventricular myocytes compared with those of timolol and atenolol. Circ $J$ 67:83-90.

Zesiewicz TA, Encarnacion E, and Hauser RA (2002) Management of essential tremor. Curr Neurol Neurosci Rep 2:324-330.

Zhang D, Ma QY, Hu HT, and Zhang M (2010) $\beta_{2}$-Adrenergic antagonists suppress pancreatic cancer cell invasion by inhibiting CREB, NFאB and AP-1. Cancer Biol Ther 10:19-29.

Zhao F, Li P, Chen SR, Louis CF, and Fruen BR (2001) Dantrolene inhibition of ryanodine receptor $\mathrm{Ca}^{2+}$ release channels: molecular mechanism and isoform selectivity. J Biol Chem 276:13810-13816.

Zorzato F, Fujii J, Otsu K, Phillips M, Green NM, Lai FA, Meissner G, and MacLennan DH (1990) Molecular cloning of cDNA encoding human and rabbit forms of the $\mathrm{Ca}^{2+}$ release channel (ryanodine receptor) of skeletal muscle sarcoplasmic reticulum. J Biol Chem 265:2244-2256.

Zorzato F, Scutari E, Tegazzin V, Clementi E, and Treves S (1993) Chlorocresol: an activator of ryanodine receptor-mediated $\mathrm{Ca}^{2+}$ release. Mol Pharmacol 44:1192-1201.

Address correspondence to: Aamir Ahmed, Centre for Stem Cells and Regenerative Medicine, 28th Floor Guy's Hospital, Tower Wing, Great Maze Pond, King's College London, London SE1 9RT, United Kingdom. E-mail: aamir.ahmed@kcl.ac.uk 